\title{
Monetary Transmission Mechanism in Sri Lanka: A Comprehensive Assessment with New Evidence
}

\author{
Anil Perera $^{1 /}$
}

\begin{abstract}
This study provides a comprehensive assessment of the transmission of monetary policy in Sri Lanka starting from changes to central bank policy to the response of final target variables-output and prices. As such, the study provides estimates for interest rate pass-through and suggests that pass-through is yet to achieve the completeness except for prime lending rates. Based on the empirical estimates obtained employing both unrestricted and structural vector auto regressions, this study observes that monetary policy in Sri Lanka is quite effective to influence the target variables of the central bank. It also suggests that monetary policy changes affect target variables through different intermediate transmission channels such as bank credit, exchange rates as well as asset prices. These results provide important policy implications for the Central Bank of Sri Lanka in the conduct of monetary policy and assessing its effectiveness.
\end{abstract}

JEL Classification: E43, E44, E52, E58

Key Words: Interest Rate Pass-through, Monetary Transmission Mechanism, Error Correction Models, Vector Auto Regressions

1/ The author is grateful to Dr. J. Wickramanayake of Monash University and Professor Deborah Ralston of Monash University and the Australian Centre for Financial Studies for the guidance and advice. The author is also thankful to Dr. P. Nandalal Weerasinghe, Ms. Swarna Gunaratne, Dr. Roshan Perera, Mr. Sunil Ratnasiri, Dr. C. Amarasekara, Dr. P. K. G. Harischandra, Dr. Hemantha Ekanayake, Dr. Sumila Wanaguru, Ms. Dimuthu Samaratunga, Ms. Erandi Liyange, Mr. Waruna Wikumsiri and Ms. Bhagya Senarathne of the Central Bank of Sri Lanka for the support and encouragement and anonymous reviewers for their valuable comments. A special mention is deserved by Mr. Lasitha Pathberiya for sharing the quarterly database for Sri Lanka and assisting some modelling exercises of this paper. 


\section{Introduction}

The consensus view is that price stability, which is one of the prime objectives of modern central banking, is achieved by appropriate monetary policy supported by other macroeconomic stabilisation policies. To that end, as argued by Mishkin (1995), monetary policy remains at the centre of macroeconomic policy making. The role of monetary policy and its success can be justified by the improved macroeconomic performance over the past few decades, especially in advanced countries. In particular, inflation and inflation volatility in advanced countries have fallen significantly, while output volatility has either fallen or risen only marginally (Cecchetti, Flores-Lagunes, and Krause, 2006). ${ }^{2 /}$ Monetary policy remains the driving force behind this improved performance, which is also supported by reductions in the variability of supply shocks and changes in the structure in economies including financial systems (Cecchetti et al., 2006).

Macroeconomic stability achieved in emerging market economies is clearly evident in the behaviour of macroeconomic variables such as inflation, growth of real output and current account deficits (Montiel and Servén, 2006). ${ }^{3 /}$ Although there is no consensus on the role of monetary policy in the emerging market economies compared to exchange rate policy and fiscal policy in macroeconomic management, it appears that monetary policy plays a credible role in terms of economic stabilisation and welfare in emerging market economies (Cook, 2004; Devereux, Lane, and Xu, 2006).

It is evident that macroeconomic aggregates are less volatile in the Sri Lankan economy during the post-1980s than in the preceding decades. According to Table 1, on average, real output variability (as measured by the standard deviation of real GDP growth) has declined from 2.1 per cent during 1950-1980 to around 1.9 per cent during 1981-2012. Despite the somewhat reversed trend during 2001-2012 (2.6 per cent) probably due to the impact of volatile domestic and external environment, broadly a declining trend is observed particularly in the 1990s recording the lowest figure of around 1.0 per cent. Volatility in prices (as measured by the standard deviation of the GDP deflator) has also declined considerably from 7.6 per cent during $1950-1980$ to around 4.3 per cent during

2/ According to World Development Indicators (WDI) of the World Bank, global inflation has declined from 17.28 per cent in 1980 to 3.67 per cent in 2012. Also during the same period, advanced country inflation has declined from 12.89 per cent to 2.44 per cent.

3/ Inflation in emerging market economies has significantly moderated from 28.29 per cent to 5.32 per cent during 1980-2012.

4/ For example, Cooper (1992) examines the challenges, i.e., costs of relying on monetary policy to combat sustained increases in price levels in emerging market economies. Little, Cooper, Corden and Rajapatirana (1993) also show that how monetary policy becomes largely an adjunct of fiscal policy and of the commitment to an exchange rate in these countries, and hence monetary policy plays a rather subsidiary role. 
Table 1: Macroeconomic Performance in Sri Lanka (1950-2012)

This table presents various indicators of macroeconomic performance in Sri Lanka for the period 1950-2012. Each column presents the average for the decade.

\begin{tabular}{|c|c|c|c|c|c|c|}
\hline Item & $1950-1959$ & $1960-1969$ & $1970-1979$ & $1980-1989$ & $1990-1999$ & 2000-2012 \\
\hline GDP Growth (\%) & 3.1 & 4.7 & 3.9 & 4.3 & 5.2 & 5.3 \\
\hline Per Capita GDP at Market Prices (US dollars) & $140.0^{*}$ & 149.6 & 231.9 & 362.5 & 706.7 & $1,300.2$ \\
\hline CPI Inflation (\%) & 0.7 & 2.2 & 6.9 & 12.8 & 11.3 & 10.9 \\
\hline GDP Deflator (\%) & 2.9 & 1.5 & 11.0 & 11.5 & 10.2 & 9.8 \\
\hline Budget Deficit ( $\%$ of GDP) & -2.9 & -6.0 & -7.1 & -11.3 & -7.9 & -8.1 \\
\hline Current Account Balance ( $\%$ of GDP) & -0.4 & -2.8 & -2.0 & -7.7 & -4.8 & -3.4 \\
\hline Interest Rate, 91-day Treasury bill Rate (\%) & 1.2 & 3.1 & 6.2 & 13.6 & 15.9 & 12.0 \\
\hline Exchange Rate (US dollar/Rupee) & 4.8 & 5.0 & 8.6 & 25.8 & 52.3 & 100.9 \\
\hline Reserve Money Growth (\%) & 4.3 & 6.6 & 15.4 & 17.9 & 14.4 & 11.4 \\
\hline Broad Money $\left(\mathrm{M}_{2}\right)$ Growth - $\mathrm{M}_{2}(\%)$ & 5.1 & 6.9 & 18.8 & 17.9 & 16.8 & 15.1 \\
\hline All Share Price Index & - & - & - & - & 727.5 & $1,786.6$ \\
\hline GDP Growth Volatility & 2.0 & 2.0 & 2.1 & 1.5 & 1.0 & 2.6 \\
\hline CPI Inflation Volatility & 1.3 & 2.7 & 4.3 & 6.7 & 4.7 & 5.4 \\
\hline GDP Deflator Volatility & 2.2 & 3.5 & 7.9 & 6.1 & 4.0 & 3.8 \\
\hline Interest Rate (91-day Treasury bill Rate) Volatility & 0.7 & 0.5 & 2.0 & 2.8 & 3.3 & 4.9 \\
\hline Exchange Rate Volatility & 0.0 & 0.5 & 3.8 & 6.0 & 10.0 & 11.5 \\
\hline Reserve Money Growth Volatility & 13.6 & 5.4 & 14.2 & 9.3 & 8.8 & 6.5 \\
\hline Broad Money $\left(\mathrm{M}_{2}\right)$ Growth Volatility & 9.4 & 4.1 & 13.4 & 7.7 & 4.7 & 3.4 \\
\hline Share Price Index Return Volatility & - & - & - & - & 48.6 & 45.2 \\
\hline
\end{tabular}

Notes: * denotes GDP per capita in 1959.

Volatility is measured by the standard deviation

Source: Updated and modified by the author based on Perera and Liyanage (2012).

1981-2012. Also monetary volatility has reduced significantly in the post-1980 period. Such macroeconomic improvement could be due to the effectiveness of monetary policy.

In particular, as the Sri Lankan economy had adopted a range of economic and financial sector reforms since the 1980s with acceleration in the 1990s, transmission of monetary policy and its effectiveness may have improved considerably. On the other hand, similar to many advanced countries and emerging market economies focusing more on price stability [for example, see Boivin, Kiley and Mishkin (2010)], monetary policy in Sri 
Lanka appears more responsive to inflationary pressures with a view to create a conducive environment for sustainable economic growth. ${ }^{5 /}$

However, despite its importance, the role of monetary policy and its transmission have not been examined extensively in the Sri Lankan context. For example, existing literature on interest rate pass-through is very limited for Sri Lanka. Amongst the available studies, Amarasekara (2005) examines interest rate pass-through and Aazim and Cooray (2012) examine monetary policy and yield curve dynamics. However, these studies do not focus on the transmission of the impact of interest rates into final policy variables and hence are limited to early stage of monetary transmission. Whether and to what extent monetary policy will be able to transmit its impact through different channels will depend crucially on the impact of policy rate innovations on market interest rates, and hence it deserves a closer examination (Égert and Jamilov, 2014). This study contributes to the ever growing literature on the interest-rate pass-through by evaluating its empirical importance for an emerging market economy, Sri Lanka. In relation to the transmission to final target variables, Jayamaha (1995) examines monetary transmission in Sri Lanka, but the study is limited to the early years of deregulation. Amarasekara (2008) also examines the effects of interest rate, money growth and the movements in nominal exchange rate on real GDP growth and inflation in Sri Lanka, and the results are broadly in line with the established empirical findings, especially when the interest rate is considered the monetary policy variable. Both studies of Amarasekara $(2005$; 2008) provide a comprehensive analysis on monetary transmission in Sri Lanka, but the sample is restricted to 2004. As there are considerable developments in the monetary policy conduct since 2004, it would be imperative to provide new empirical evidence for both interest rate pass-through and monetary transmission within the context of a single study. As such, this study serves this purpose by providing a comprehensive assessment of the monetary transmission mechanism in Sri Lanka.

The remainder of the paper is structured as follows: Section 2 briefly discusses the developments of monetary policy conduct in Sri Lanka. Section 3 provides relevant theoretical underpinnings and Section 4 presents a discussion on the data and methodology of the study. Section 5 presents empirical estimates and related discussion, Section 6 is devoted to summary and conclusions.

5/ Communications of the Central Bank of Sri Lanka (CBSL) indicate that its primary responsibility is to fight inflation while securing financial system stability (Central Bank of Sri Lanka, 2011; 2012). 


\section{Financial and Monetary Policy in Sri Lanka: A Brief Snapshot of Historical Developments}

Since the establishment of the Central Bank in 1950 under the Monetary Law Act, (No. 58 of 1949), monetary policy in Sri Lanka has evolved to achieve both the economic stabilisation objective and the development objective (Central Bank of Sri Lanka, 1998). Since inception, the Central Bank has exercised multiple objectives such as stabilisation of domestic monetary values, preservation of the stability of the exchange rate, promotion of a high level of production, employment and real income and encouragement and promotion of development of productive resources. Hence, the Central Bank was required to align its monetary policy to achieve these two broad objectives. The Monetary Law Act also provided the Central Bank with an array of instruments to implement monetary policy and the main instruments include operations in foreign exchange (external reserve management, changes in the exchange rate and exchange control regulations), credit operations with banking institutions (refinance facilities and other credit to commercial banks and other financial institutions and lender of last resort facilities), reserve requirements on commercial bank deposits, quantitative restrictions on credit, interest rate management, open market operations and the use of moral suasion. Amongst different monetary policy tools, open market operations were particularly used in the 1950s and in the post 1985 period. At the same time, the Bank Rate and the Statutory Reserve Requirement (SRR) have been used extensively. However the Bank Rate has not been used after the mid-1980s. Direct controls have served as the more important monetary policy tools in the closed economy era of the 1960s and 1970s (Central Bank of Sri Lanka, 1998). In line with such practices, two major issues can be identified in regards to implementing monetary policy in Sri Lanka, i.e. the relatively underdeveloped nature of financial markets and the lack of congruence between fiscal policy and monetary policy (Central Bank of Sri Lanka, 1998). In fact, the financial system has been regulated for a long period of time displaying specific characteristics such as interest rate controls, directed lending, inefficient banking system, capital controls, institutional deficiencies, etc. (Cooray, 2000; Paudel and Jayanthakumaran, 2009). On the other hand, from the 1950 s to the 1990 s, fiscal policy has been expansionary, compelling monetary policy to be contractionary to dampen inflationary pressures emanating from high fiscal deficits (Central Bank of Sri Lanka, 1998).

The Sri Lankan economy has embarked on a wide range of liberalisation policies since 1977. The policy reform package contained various measures and strategies such as trade liberalisation, exchange rate realignment, financial sector reforms, etc. (Cuthbertson and Athukorala, 1990). Particularly, the financial sector reforms package included several measures such as changes to interest rate policy, lifting entry barriers in the banking sector, phasing-out interest rate subsidy schemes, encouraging market-driven financial products, 
and strengthening the regulatory framework, etc. (Athukorala and Rajapatirana, 1993; Perera, 2014). More importantly, interest rates have been deregulated since the early 1980s (Athukorala and Rajapatirana, 1993) and stock market liberalisation was a significant event of the reform agenda (Alles, 2008; Perera and Wickramanayake, 2012). During the period of economic liberalisation, coordination was developed among monetary policy, fiscal policy and exchange rate policy (Central Bank of Sri Lanka, 1998). In 2001, Sri Lanka marked a significant step by moving towards a free-floating exchange rate system and subsequently modifying the monetary policy framework while placing greater emphasis on market based monetary policy instruments (Central Bank of Sri Lanka, 2005).

In response to the changing economic environment, the Monetary Law Act was also amended in 2002 to streamline central bank objectives and to focus on two key objectives: economic and price stability and financial system stability (Central Bank of Sri Lanka, 2005). Monetary management in Sri Lanka relies on a monetary targeting framework and under this framework, the final target, price stability, is to be achieved by influencing the changes in broad money supply which is linked to reserve money (operating target) through a multiplier. Currently, to achieve monetary targets and thereby final objectives, the monetary policy framework predominantly relies on indirect monetary instruments such as open market operations and interest rates management (Central Bank of Sri Lanka, 2011).

As a continuation to the modifications to the monetary policy framework, at the beginning of 2011, the CBSL adopted a more dynamic dual approach to its monetary policy analysis. Accordingly, a broader and more in-depth analysis of economic developments is carried out parallel to the analysis of monetary developments. This approach is expected to supplement the existing monetary targeting framework and strengthen the control over demand driven inflationary pressures (Central Bank of Sri Lanka, 2010).

\section{Theoretical Underpinnings of Monetary Transmission Mechanism}

\subsection{Transmission from Monetary Policy Changes to Market Interest Rates}

The monetary transmission mechanism (MTM hereafter) illustrates how policy-induced changes in monetary policy instruments of a central bank (the nominal money stock or the short-term nominal interest rate) influence real variables such as aggregate output and employment and the key nominal variable: inflation (Mishkin, 1995; Taylor, 1995). MTM begins with a change to central bank policy and then proceeds via different active channels such as interest rates, exchange rates, asset prices, credit as well as expectations (Mishkin, 1995; Woodford, 2003). 
Figure 1: Interest Rate Pass-Through and Monetary Transmission Mechanism

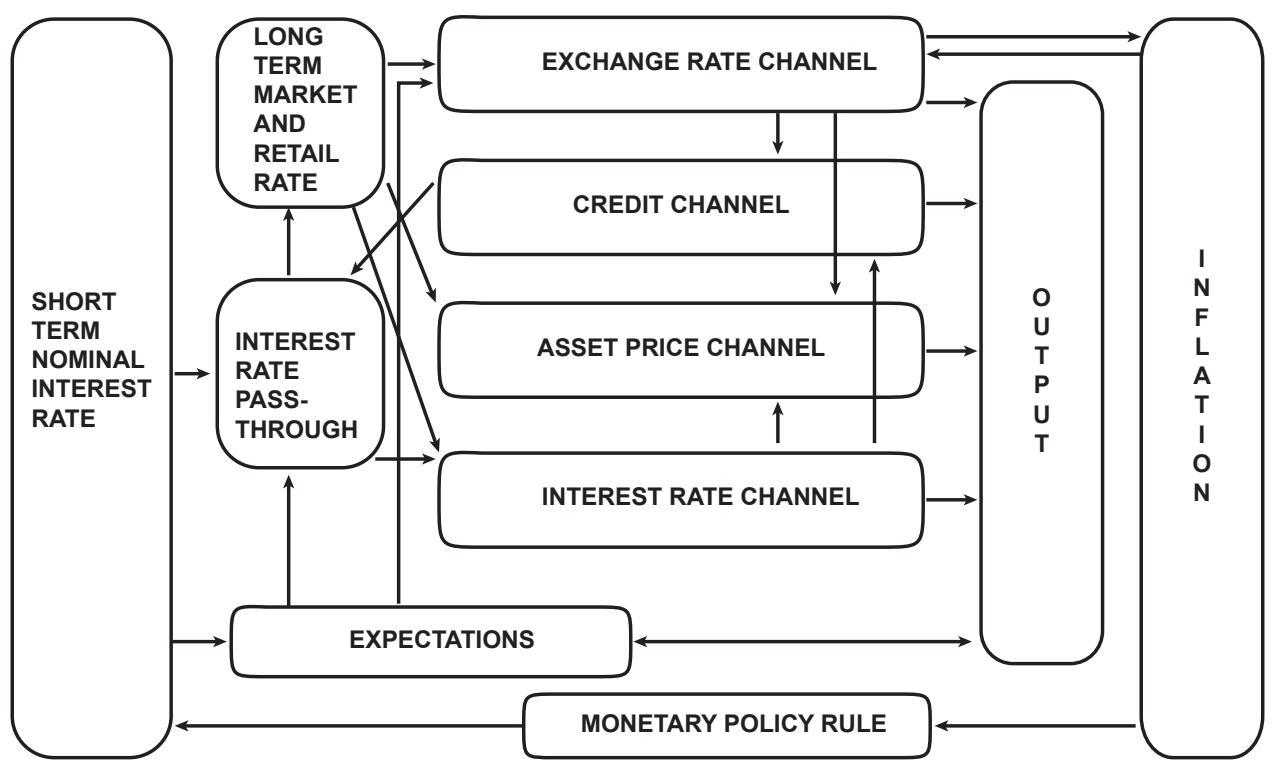

Source: Adopted from Égert and MacDonald (2009).

In the process of transmission, interest rate pass-through (IRPT hereafter) becomes an important and essential element. Figure 1 provides a schematic overview of different channels of MTM and the ways they are interrelated and it mainly suggests that IRPT is the first and foremost step of the entire MTM. The process of IRPT can be decomposed into two stages (De Bondt, 2005). The first stage describes how changes in central bank monetary policy rates are transmitted to short- and long-term market rates while the second stage measures how changes in the market rates influence retail interest rates (lending and deposit rates). ${ }^{6 /}$ The 'cost of funds approach' described by De Bondt (2005) is considered the best way to describe this second stage (Égert et al., 2007). Accordingly, based on the idea of price setting by banks, i.e. mark-up pricing model of Rousseas (1985), De Bondt

6/ The first stage is largely influenced by the stability of the yield curve and hence the connection between short- and long-term interest rates is basically established by the term structure of interest rates (De Bondt, 2005). If the term structure (yield curve) remains stable over time, pass-through from policy rates to market interest rates is said to be proportionate. The slope and the dynamics of term structure is well explained employing a combination of standard prepositions like liquidity preference and market segmentation theories and also based on the expectations theory of yield curve (De Bondt, 2005; Égert, Crespo-Cuaresma, and Reininger, 2007). 
(2005) explains the connection between money market and retail interest rates. According to this model, the price set by a financial institution, i.e., retail interest rate $i^{\text {B }}$ equals to marginal cost of funding approximated by a comparable marke interest rate $i^{\mathrm{M}}$ and a constant mark-up $\alpha$ as shown in the following specification (De Bondt, 2005):

$$
i^{\mathrm{B}}=\alpha+\beta . i^{\mathrm{M}}
$$

In this Eq. (1), $\beta$ represents the pass-through parameter (degree of long run IRPT) and it depends on the demand elasticity of loans and deposits with respect to retail interest rates. If the demand for loans and deposits is not fully elastic, parameter $\beta$ is expected to be less than unity. In other words, $\beta$ is equal to 1 in the case of a complete pass-through, i.e. 'completeness hypothesis' holds (De Graeve, De Jonghe, and Vennet, 2007). It is argued that speedy and complete IRPT leads to strengthen the entire MTM and thus affects price stability (De Bondt, 2005). To that end, a complete and faster IRPT implies that monetary policy is quite effective. In contrast, an incomplete and slower (disproportionate) IRPT suggests that monetary policy is less effective requiring long lags in influencing aggregate demand. ${ }^{7 /}$

A complete IRPT may not be observed due to several reasons such as menu costs, high switching costs, imperfect competition, and asymmetric information (Chong, Liu, and Shrestha, 2006). The menu costs hypothesis suggests that financial firms are reluctant to re-quote the prices of their products if changes in those prices are deemed to be very small and/or temporary in nature. The switching costs hypothesis argues that uninformed customers are less likely to switch financial products and/or institutions in search of the best price (or yield) when there are (perceived or real) high switching costs (Chong et al., 2006). According to the imperfect competition hypothesis, interest rates are likely to adjust more slowly in uncompetitive markets (Hannan and Berger, 1991). ${ }^{8 /}$ As discussed by Stiglitz and Weiss (1981), the asymmetric information hypothesis states that banks encounter both adverse selection and moral hazard problems when they need to raise lending rates in response to rising market interest rates. In view of these problems, banks are generally reluctant to raise lending rates but they are more likely to ration the amount of credit extended when there is upward pressure on lending rates. Taken together,

7/ As Marotta (2009) argues, an incomplete IRPT could actually violate the Taylor principle - that a central bank should raise its interest rate instrument more than one-to-one with the increase in inflation, and as a result monetary policy would fail to be stabilising. Hofmann and Mizen (2004) however argue that while complete IRPT is more efficient in its ability to control inflation, incomplete IRPT is still effective if it is predictable.

8/ This can also be discussed under the preposition of collusion leading to asymmetric adjustment (Heffernan, 1997; Fuertes and Heffernan, 2009). Because of the collusive price arrangement among banks, rate adjustments in uncompetitive markets can be asymmetric, i.e., deposit rates are expected to be rigid upwards, while lending rates are expected to be rigid downwards (Chong et al., 2006). 
if the banking system is perfectly competitive and information is totally transparent, then the market price will be equal to the marginal cost. In that case, price changes perfectly reveal the changes of the marginal cost in Eq. (1), so the ratio of the price change to the marginal cost change is $1(\beta=1) .^{9 /}$

Several studies have shown that the short run adjustment in interest rates may be asymmetric, i.e., adjustment speed may differ when rates are further away from equilibrium (Scholnick, 1996; 1999; Chong et al., 2006; Sander and Kleimeier, 2006; Liu, Margaritis, and Tourani-Rad, 2008; Chong, 2010). Such asymmetry of IRPT needs to be specifically considered as it distorts the MTM (Scholnick, 1996). This is because expansionary and restrictive monetary policy would have differential impacts on the economy and hence the transmission will not be uniform (De Bondt, 2005; Chong, 2010).

Based on this theoretical guidance, it is expected to provide short run and long run estimates for IRPT based on the Sri Lankan context and to assess the effectiveness of interest rate adjustment while focusing on asymmetric adjustments.

\subsection{Transmission from Market Interest Rates to Target Variables through Different Channels}

The response of macroeconomic aggregates to monetary policy shocks is explained by Bernanke and Gertler (1995) as follows: (i) Although an unanticipated tightening in monetary policy has only transitory effects on interest rates, monetary tightening is followed by a sustained decline in output and prices; (ii) Falling relatively quickly after a change in policy, final demand absorbs the initial impact of monetary tightening (production also falls with a lag implying that inventories could rise in the short run, but declines later); (iii) The earliest and the sharpest declines in final demand can be seen in residential investment; (iv) Fixed business investment eventually declines in response to monetary tightening after housing and consumer durables. Thus, the effectiveness of monetary policy can be gauged by models of MTM, which show the dynamic responses of key economic aggregates targeted by the central bank, i.e., output and prices, to an unanticipated tightening of monetary policy. Moreover, theories of MTM assume that prices react to monetary policy with a longer lag than output (Kilponen and Leitemo, 2011). This is because nominal prices cannot adjust immediately and proportionately following a change in monetary policy due to the degree of frictions in the economy (Ireland, 2008; Walsh, 2010).

9/ Switching and menu costs are more likely to be primary factors in influencing the short-term adjustment speed whereas imperfect competition and asymmetric information are more likely to be primary factors in affecting the long-term adjustment process (Chong et al., 2006). 
A number of propagation mechanisms, i.e., different channels of MTM are identified in the monetary economics literature. For example, Mishkin (1995) describes various channels through which monetary policy actions affect the economy: (i) interest rate channel, (ii) exchange rate channel, (iii) other asset prices channel, and (iv) credit based channels. $^{10 /}$

Amongst different channels, interest rates and the credit view deserve much attention as monetary policy actions affect credit flows and the economy either from the 'interest rate side' or from the 'credit side' (Romer and Romer, 1994). The impact of interest rates on the components of aggregate demand is considered as the interest rate or money view, i.e., the traditional channel (Bernanke and Blinder, 1988; Morris and Sellon, 1995), which is also treated as the primary/central transmission channel (Taylor, 1995; Sellon, 2002). ${ }^{11 /}$ It is however argued that policy-induced changes in the cost of capital (through interest rates) are insufficient to explain the size, timing and the composition of economic responses to a monetary policy shock (Bernanke and Gertler, 1995; Kandrac, 2012) as market imperfections play a pivotal role in MTM through the so-called 'credit channels' (Kashyap and Stein, 1995). Such channels arise mainly through asymmetric information and the imperfect nature of credit markets (Gertler and Gilchrist, 1993) that depend on several features of the financial system. These financial market frictions and imperfections amplify the effects of monetary policy mainly through two distinct sub-channels: the 'bank lending channel' and the 'balance sheet channel' (Bernanke and Blinder, 1988; Mishkin, 1995). The bank lending channel suggests that monetary policy is transmitted through the supply of bank loans (Kashyap and Stein, 1995). The balance sheet channel focuses on the role of financial positions of private agents play in the MTM, which operates through borrowers' balance sheets (Aysun and Hepp, 2011).

The exchange rate channel works through the changes in the currency value and the adjustments in net exports affecting aggregate demand directly, while the asset price

10/ Taylor (1995) classifies these channels into two broad categories: (i) financial market prices (short-term interest rates, bond yields, exchange rates), and (ii) financial market quantities (money supply, bank credit, supply of government bonds, foreign denominated assets). Boivin et al. (2010) differentiate channels of MTM into two broad strands: (i) neo-classical channels in which financial markets are perfect, and (ii) non-neo-classical channels that involve financial market imperfections. These neo-classical channels are built upon core models of investment, consumption, and international trade behaviour (i.e., direct interest rate channel) as well as Tobin's q, wealth effects, intertemporal substitution effects and exchange rate channels. The non-neo-classical channels refer to the credit view, which includes effects on credit supply from government interventions in credit markets, bank-based channels (through lending and bank capital), and balance sheet channel (affecting both firms and households).

11/ This view claims that changes to central bank monetary policy stance influence real economic activity through interest rates affecting the opportunity cost of capital. It also takes bonds and loans to be perfect substitutes and only allows for the monetary policy effects on aggregate investment, consumption and savings through changes in interest rates (Bolton and Freixas, 2006). 
channel operates mainly through capital (stock) markets and real estate markets. Hence, these channels are based on the investment decisions of firms and households (Mishkin, 1995; Boivin et al., 2010) as well as the financial wealth of the investors having implications on the aggregate demand (Sellin, 2001). In addition to these core channels, expectations have also gained some attention in contemporary literature (Roberts, 1998; Svensson, 1999). Table 2 provides a schematic overview of different transmission channels including key sub-channels.

\section{Table 2: Stylised Illustration of Key Channels of Monetary Transmission}

This table shows the workings of key channels of monetary transmission. The table is compiled by the author based on Mishkin (1995); Taylor (1995) and Boivin et al. (2010).

\begin{tabular}{|c|c|}
\hline Channel & Causation Chains \\
\hline \multicolumn{2}{|l|}{ Interest Rate Channel } \\
\hline - Nominal Variant & Money $\uparrow \rightarrow$ Interest Rate $\downarrow \rightarrow$ Investment $\uparrow \rightarrow$ Aggregate Demand $\uparrow$ \\
\hline - Real Variant & $\begin{array}{l}\text { Money } \uparrow \rightarrow \text { Expected Price } \uparrow \rightarrow \text { Expected Inflation } \uparrow \\
\rightarrow \text { Real Interest Rate } \downarrow \rightarrow \text { Investment } \uparrow \rightarrow \text { Aggregate Demand } \uparrow\end{array}$ \\
\hline \multicolumn{2}{|l|}{ Open Economy Channel } \\
\hline - Exchange Rate Channel & $\begin{array}{l}\text { Money } \uparrow \rightarrow \text { Interest Rate } \downarrow \rightarrow \text { Exchange Rate } \uparrow \text { (Depreciates) } \\
\rightarrow \text { Exports } \uparrow \rightarrow \text { Net Exports } \uparrow \rightarrow \text { Aggregate Demand } \uparrow\end{array}$ \\
\hline \multicolumn{2}{|l|}{ Credit Channel } \\
\hline - Bank Lending & $\begin{array}{l}\text { Money } \uparrow \rightarrow \text { Deposits } \uparrow \rightarrow \text { Bank Loans } \uparrow \rightarrow \text { Investment } \uparrow \\
\rightarrow \text { Aggregate Demand } \uparrow\end{array}$ \\
\hline - Balance Sheet & $\begin{array}{l}\text { Money } \uparrow \rightarrow \text { Price of Stocks (Net Worth) } \uparrow \rightarrow \text { Adverse Selection } \downarrow \\
\rightarrow \text { Moral Hazard } \downarrow \rightarrow \text { Lending } \uparrow \rightarrow \text { Investment } \uparrow \\
\rightarrow \text { Aggregate Demand } \uparrow\end{array}$ \\
\hline - Cash Flow & $\begin{array}{l}\text { Money } \uparrow \rightarrow \text { Interest Rate } \downarrow \rightarrow \text { Cash Flow } \uparrow \rightarrow \text { Adverse Selection } \downarrow \\
\rightarrow \text { Moral Hazard } \downarrow \rightarrow \text { Lending } \uparrow \rightarrow \text { Investment } \uparrow \rightarrow \text { Aggregate Demand } \uparrow\end{array}$ \\
\hline - Unanticipated Price Level & $\begin{array}{l}\text { Money } \uparrow \rightarrow \text { Unanticipated Price of Stocks } \uparrow \rightarrow \text { Adverse Selection } \downarrow \\
\rightarrow \text { Moral Hazard } \downarrow \rightarrow \text { Lending } \uparrow \rightarrow \text { Investment } \uparrow \rightarrow \text { Aggregate Demand } \uparrow\end{array}$ \\
\hline - Liquidity Effects & $\begin{array}{l}\text { Money } \uparrow \rightarrow \text { Price of Stocks } \uparrow \rightarrow \text { Value of Financial Assets } \uparrow \\
\rightarrow \text { Likelihood of Financial Distress } \downarrow \\
\rightarrow \text { Consumer Durables and Housing Expenditure } \uparrow \rightarrow \text { Aggregate Demand } \uparrow\end{array}$ \\
\hline \multicolumn{2}{|l|}{ Other Channels } \\
\hline - Wealth Effect & $\begin{array}{l}\text { Money } \uparrow \rightarrow \text { Price of Stocks } \uparrow \rightarrow \text { Wealth } \uparrow \rightarrow \text { Consumption } \uparrow \\
\rightarrow \text { Aggregate Demand } \uparrow\end{array}$ \\
\hline - Tobin's q & $\begin{array}{l}\text { Money } \uparrow \rightarrow \text { Price of Stocks } \uparrow \rightarrow \text { Tobin's } q \uparrow \rightarrow \text { Investment } \uparrow \\
\rightarrow \text { Aggregate Demand } \uparrow\end{array}$ \\
\hline - Expectations & $\begin{array}{l}\text { Money } \uparrow \rightarrow \text { Expected Inflation } \uparrow \rightarrow \text { Consumption/Investment } \uparrow \\
\rightarrow \text { Aggregate Demand } \uparrow\end{array}$ \\
\hline
\end{tabular}


In this study, it is expected to examine whether empirical evidence on the effects of monetary policy on output and prices in Sri Lanka corresponds with existing theoretical explanations and empirical findings. Specifically, it will be tested whether target variables of the central bank - output and prices respond following a monetary policy shock. At the same time, it is expected to examine the response of other key macroeconomic aggregates such as money and exchanges rates and the working of different intermediate channels in transmitting monetary policy.

\section{Data and Methodology}

\subsection{Transmission from Monetary Policy Changes to Market Interest Rates}

The policy interest rate (CBR) is the key interest rate directly administered by a central bank. However, empirical exercises generally rely on proxy rates for monetary policy indicators in place of central bank policy rates, as policy rates do not provide econometrically appealing results. The standard proxies used are the short-term money market rates, i.e., either overnight interbank rate or the Treasury bill rate. Accordingly, as in Amarasekara (2005), preliminary empirical models of this study are estimated using the weighted average of interbank call money rates (MMR). However, co-integrations between the retail rates and the MMR were not observed for most of the cases leading to insignificant and inconsistent results. This could be due to higher volatility in the MMR, which is largely attributed to liquidity fluctuations arising mainly from the impact of foreign exchange operations of the CBSL and the changes in liquidity demand by commercial banks, particularly due to government fiscal operations. Thus, following previous empirical literature, for example, Cottarelli and Kourelis (1994); Espinosa-Vega and Rebucci (2004) and Haughton and Iglesias (2012), the 3-month Treasury bill rate (TBR) is employed as the main exogenous rate, i.e., monetary policy indicator. It remains the appropriate rate that influences monetary policy in the absence of interbank rates (Haughton and Iglesias, 2012). ${ }^{12 /}$

To provide empirical estimates for IRPT, aggregate (average) monthly interest rate data are used for the period January 1990 to December 2012. In addition to the 3-month Treasury bill rates (TBR), the sample consists of average bank lending rates (LR) and deposit rates (DR). Average bank lending rates include average prime lending rates (AWPR) for licenced commercial banks (LCBs) and average lending rates (LRS) for licenced specialised banks (LSBs). Average bank deposit rates include average savings rates and average fixed deposit rates (AWDR and AWFDR) for LCBs and average deposit rates

12/ A strong correlation between CBR and TBR is also observed. 
(DRS) for LSBs. The data are mainly obtained from International Financial Statistics (IFS) and the CBSL.

Prior to conducting the empirical analysis, first, contemporaneous correlation coefficients between the money market rates and the retail interest rates are examined as the basic indicators of IRPT (Bredin, Fitzpatrick, and O'Reilly, 2002). Second, unit root tests for each interest rate series are conducted to examine the stationary property of the data using the augmented Dickey-Fuller (ADF) and Phillips-Perron (PP) unit root tests. Thereafter, the Johansen (1988) maximum likelihood procedure is used to examine co-integration between each retail rate and the money market rates. Moreover, standard Granger causality tests (Granger, 1969; 1981) are used to gain a preliminary insight into the nature of the temporal relationships among interest rates and hence, to examine whether changes in money market rates cause changes in retail rates (Diebold and Sharpe, 1990; Chong et al., 2006).

The main empirical approach of this part of study is based on the existing literature, for example, Heffernan (1997); Disyatat and Vongsinsirikul (2003); De Bondt (2005); Chong et al., (2006); Hofmann (2006); De Graeve et al., (2007); Liu et al., (2008); Chong (2010). Accordingly, standard error correction models (ECM) are used to determine empirical estimates of IRPT. The ECM method seems suitable to estimate IRPT since it provides an economically appealing interpretation of model parameters (De Bondt, 2005; Chong et al., 2006). In particular, ECMs based on the single-equation approach is considered appropriate to model both short- and long run pass-through of interest rates (Heffernan, 1997; Bredin et al., 2002).

Accordingly, being guided by the cost of funds approach (Rousseas, 1985; De Bondt, 2005) described by Eq. (1), the long run relationship between the endogenous retail interest rate and the exogenous money market rate is established as follows:

$$
R_{t}=\alpha_{0}+\alpha_{1} M_{t}+\varepsilon_{t}
$$

where, $R_{t}$ is the relevant endogenous retail interest rate (lending or deposit rate), $M_{t}$ is the exogenous short-term money market rate (proxy for the central bank policy rate) and $\varepsilon_{t}$ is the error term. $\alpha_{0}$ and $\alpha_{1}$ measure the constant mark-up (or mark-down) and the degree of long run pass-through, respectively. If $\alpha_{1}=1$, long run IRPT is complete, and to ascertain the completeness, the standard Wald test is used to determine whether $\alpha_{1}=1$. If $\alpha_{1}$ is less than unity, IRPT is said to be incomplete.

In order to examine short run dynamics of IRPT and to determine the extent that takes retail interest rates to fully adjust in response to changes in money market rates, 
an ECM representation corresponding to a general auto regressive distributed lag (ARDL) $(p, q)$ model is specified. This is based on the Engle and Granger (1987) error correction procedure. Accordingly, the following model is applied to examine short run adjustments:

$$
\Delta R_{t}=\beta_{1} \Delta M_{t}+\beta_{2}\left(R_{t-1}-\alpha_{0}-\alpha_{1} M_{t-1}\right)+v_{t}
$$

where, $\Delta$ denotes first differenced operator and $v_{t}$ is the error term. $\mathrm{R}_{(t-1)}$ and $\mathrm{M}_{(t-1)}$ are lagged variables and the relevant lag structure is determined by the general to specific method (Mojon, 2000; Bredin et al., 2002) and is based on the information criteria of lag selection.

Eq. (3) characterises the reduced form of the dynamic relationship between retail interest rates and money market rates and the term in brackets represents the lagged deviation of retail interest rate from its steady state equilibrium value, or in general, the error correction term. In this model, $\beta_{1}$ measures short run (immediate, contemporaneous or impact) passthrough, i.e., the degree of the change in retail interest rate in response to a change in money market rate during the same period. $\hat{\varepsilon}_{(t-1)}=\left(\mathrm{R}_{t-1}-\alpha_{0}-\alpha_{1} M_{t-1}\right)$ represents the extent of retail rate disequilibrium at time $(t-1)$, which is the residual of the long run relationship modelled by Eq. (2). Hence, $\beta_{2}$ captures the error correction adjustment speed to the long run value when the rates are away from their equilibrium level. In the mean reverting case of interest rates, sign of $\beta_{2}$ is expected to be negative and the absolute size of the coefficient indicates how fast a disequilibrium in retail interest rate settings will be removed (Chong et al., 2006; Liu et al., 2008). Moreover, mean adjustment lag (MAL) of a complete pass-through can be calculated as follows using the approach suggested by Hendry (1995):

$$
\left(1-\beta_{2}\right) / \beta_{2}
$$

Eq. (4) indicates the average months needed to reach the long run value of pass-through, i.e., speed at which the market interest rate is fully passed-through to retail rates (Hendry, 1995). It takes into account the proportion of the adjustment, which takes place in the first period and the total adjustment in the long run. Robustness of these results obtained from the ECM estimates are formally checked by estimating bivariate VAR models and comparing impulse responses as suggested by Diebold and Sharpe (1990); De Bondt (2005) and Berument and Froyen (2006).

Thereafter, to examine the asymmetric adjustment when the rates are above or below the equilibrium, an indicator (dummy) variable $\lambda$ is created and incorporated into Eq. (3). 
$\lambda$ is equal to 1 if the residual $\hat{\varepsilon}_{(t-1)}=\left(\mathrm{R}_{t-1}-\alpha_{0}-\alpha_{1} M_{t-1}\right)$ is positive and 0 otherwise. Hence, the asymmetric short run dynamic equation can be specified as follows:

$$
\Delta R_{t}=\delta_{1} \Delta M_{t}+\delta_{2} \lambda \hat{\varepsilon}_{t-1}+\delta_{3}(1-\lambda) \hat{\varepsilon}_{t-1}+\eta_{t}
$$

where, $\delta_{2}$ captures the error correction adjustment speed when the rates are above the equilibrium and $\delta_{3}$ captures the error correction adjustment speed when the rates are below the equilibrium values. A Wald test is used to determine if $\delta_{2}$ is significantly different from $\delta_{3}$ and hence to examine the presence of asymmetric adjustment. Similar to the case of symmetric adjustment, asymmetric MALs for a complete IRPT from money market rates to retail rates can be defined as follows:

$$
\begin{aligned}
\mathrm{MAL}^{+} & =\left(1-\delta_{1}\right) / \delta_{2} \\
\mathrm{MAL}^{-} & =\left(1-\delta_{1}\right) / \delta_{3}
\end{aligned}
$$

Mean adjustment lag when the rates are above their equilibrium value is given by $\mathrm{MAL}^{+}$ and when rates are below their equilibrium value is represented by $\mathrm{MAL}^{-}$(Chong et al., 2006; Liu et al., 2008).

\subsection{Transmission from Market Interest Rates to Target Variables through Different Channels}

In order to provide empirical estimates under this section, quarterly data for the period March 1996 - December 2012 are used. The required data are mainly obtained from the published databases of the CBSL and the IFS.

The empirical approach of this study is based on estimating vector auto regression (VAR) models. VAR models have been progressively used for emerging market studies such as Agung (1998) for Indonesia, Disyatat and Vongsinsirikul (2003); Charoenseang and Manakit (2007) for Thailand and Elbourne and de Haan (2006) for some transition countries, among others.

First, to establish MTM and to examine the effectiveness of monetary policy in Sri Lanka, an unrestricted-baseline VAR model is estimated. This model assumes that the system is recursive and hence the Choleski decomposition is employed for identification. The estimated baseline VAR specification can be written in following matrix form:

$$
y_{t}=k+A(L) y_{t-1}+B \mathrm{x}_{t}+u_{t}
$$


where, $y_{t}$ is the vector of endogenous variables, $k$ is the vector of constants, $x_{t}$ is the vector of exogenous variables and $u_{t}$ is the vector of serially uncorrelated disturbances that have a zero mean and a time invariant covariance matrix. $A(L)$ denotes a matrix polynomial in the lag operator $\mathrm{L}$ and $\mathrm{B}$ is a coefficient matrix. In the baseline specification, the vector of endogenous variables i.e., $y_{t}$ consists of key variables: real gross domestic product $\left(\mathrm{GDP}_{t}\right)$, consumer price index $\left(\mathrm{CPI}_{t}\right)$, a measure of monetary aggregate, i.e., narrow money supply $\left(\mathrm{M} 1_{t}\right)$ and the domestic nominal short-term interest rate given by the interbank money market rate $\left(\mathrm{MMR}_{t}\right)$, and hence can be written as follows. ${ }^{13 /}$

$$
y_{t}^{\prime}=\left(\begin{array}{llll}
G D P_{t} & C P I_{t} & M 1_{t} & M M R_{t}
\end{array}\right)
$$

$G D P_{t}$ and $C P I_{t}$ are the key target variables of the monetary authority, which respond to innovations to the monetary policy rate $\left(M M R_{t}\right)$. The use of narrow money aggregate $\left(M I_{t}\right)$ is guided by prior literature, for example, Sims (1992); Berument and Froyen (2006); Ito and Sato (2008); Rafiq and Mallick (2008); Laopodis (2013) to incorporate the impact of liquidity into the VAR system. ${ }^{14 /}$ The use of the money market rate $\left(M M R_{t}\right)$ as the monetary policy indicator is also guided by prior literature such as Ito and Sato (2008); Rafiq and Mallick (2008), and it captures the exogenous shifts in the monetary policy stance (Gertler and Gilchrist, 1993). ${ }^{15 /}$ The ordering of variables is consistent with the central bank response to output and inflation dynamics and the dynamic structure of the economy (Disyatat and Vongsinsirikul, 2003). Therefore, the policy variable $\left(M M R_{t}\right)$ is ordered last implying that an innovation in the money market rate has no contemporaneous impact on the variables in the system but has only a lagged influence on the other variables (Gertler and Gilchrist, 1993; Garretsen and Swank, 1998). A dummy variable is also included in the model to capture the impact of the structural break that occurred in 2001 due to exchange rate liberalisation. However, the impact of the global financial crisis is not considered in this model as there was no structural break in the data, which is consistent with the approach used in a study of Carpenter and Demiralp (2012).

Following Gerlach and Smets (1995); Berument and Froyen (2006); Hesse (2007); Carpenter and Demiralp (2012), among others, all non-interest rate variables are measured in natural logarithms. Also, based on the widely used X-11 procedure for seasonal adjustment, variables are seasonally adjusted. If the variables in the system are non-stationary, but co-integrated, Sims, Stock and Watson (1990) and Lütkepohl and

13/ Generally, baseline VAR models include four key variables, i.e., real output, inflation rates, nominal interest rate and a financial variable of interest (for example, monetary aggregates) (Gertler and Gilchrist, 1993).

14/ Base or narrow money allows for the effect of monetary policy on inflation (Ito and Sato, 2008).

15/ In the previous section, the 3-month Treasury bill rate is used as the monetary policy indicator to estimate IRPT in Sri Lanka due to the high volatility in the interbank money market rates. However, based on the standard MTM literature, interbank money market rate is used in this analysis. 
Reimers (1992) prescribe that estimating VARs in (log) levels will provide consistent estimates. Although there is loss of efficiency in the VAR due to estimations in levels, it will prevent the loss of information about the long run relationships when a VAR is estimated in first differences. Accordingly, being guided by similar prior research, for example, Disyatat and Vongsinsirikul (2003); Iacoviello and Minetti (2003); Berument and Froyen (2006), among others, an unrestricted VAR model is estimated in levels. ${ }^{16 /}$ Impact of monetary policy shocks on the target variables are identified based on impulse response functions (IRFs). Also, in order to get an idea about the share of fluctuations in a given variable that are caused by different shocks, variance decompositions (forecast error decompositions) for each variable at different forecast horizons are also estimated.

Thereafter, a structural VAR (SVAR) model is estimated for Sri Lanka. This SVAR model is consistent with economic theory and it imposes enough restrictions to identify policy shocks, which recognise the intertwines and complex relationships between policy variables and other macroeconomic variables (Leeper, Sims, and Zha, 1996; Boivin and Giannoni, 2006). Importantly, the SVAR approach is better suited for small open economies like Sri Lanka than the traditional identification methods. This is because of its ability to capture more of the salient features of such economies (Elbourne and de Haan, 2006). ${ }^{17 /}$ To that end, using a SVAR model for the Sri Lankan economy is well justified due to several reasons. First, being an open economy, the SVAR model can uncover the interdependence between the domestic monetary policy instrument variable and the nominal exchange rate. Second, although the short-term interest rate remains the main policy variable, the CBSL targets monetary aggregates (base/reserve money) as its operating target. Hence, it is not clear or hard to determine the most appropriate monetary policy instrument used to identify monetary policy shocks. The SVAR model considers combinations of monetary aggregates and short-term interest rates, helping to identify monetary policy shocks appropriately. Third, a SVAR model is preferred as it takes no account of the time series properties of the data (Dale and Haldane, 1995; MacDonald, Mullineux, and Sensarma, 2009) also and due to relatively small sample size (MacDonald et al., 2009).

Guided by the prior literature, mainly Kim and Roubini (2000), the following seven variables are included in the model: global commodity price index of the IMF $\left(\operatorname{COMP}_{t}\right)$, US Federal funds rate $\left(F E D R_{t}\right)$, real output $\left(G D P_{t}\right)$, consumer price index $\left(C P I_{t}\right)$, money stock given by narrow money $\left(M l_{t}\right)$, short-term domestic interest rate given by the

16/ As indicated by the unreported results, the ADF and PP tests all fail to reject a unit root in the levels of these time series but can be rejected in the first differences. Also, both Johansen's $\lambda$-max and $\lambda$-trace tests decisively reject the hypothesis of no cointegration for both sets of variables.

17/ In general, Kim and Roubini (2000) argue that SVARs resolve a number of anomalies related to exchange rates, prices and liquidity, which are detected in the empirical small open economy recursive VAR models. 
interbank money market rate $\left(M M R_{t}\right)$ and the nominal exchange rate (Sri Lankan rupee with respect to US dollar - EXR . All these variables are seasonally adjusted and specified in logs except for interest rates. Before estimating the SVAR model, first, an unrestricted VAR model is estimated and is diagnosed for stability, absence of autocorrelation and heteroskedasticity. Then, the same model is augmented in the SVAR setting, which is identified by several short run restrictions as discussed in Appendix I.

Using the 7-variable SVAR model, structural innovations for an unanticipated positive interest rate shock (restrictive monetary policy) are obtained and the variance decompositions are estimated. Also, models are re-estimated using some alternative variables in order to ensure the validity of the 7-variable SVAR model.

After establishing monetary transmission, the workings of different channels are examined based on the extensions to the baseline VAR model. Accordingly, to identify the workings of the particular channel, the shutdown/blocking-off method is used as in the studies of Morsink and Bayoumi (2001) and Disyatat and Vongsinsirikul (2003). As such, to gauge the relative strength of different channels, IRFs for target variables (output and prices) are compared under two scenarios: (i) estimates with relevant channel endogenous versus (ii) estimates with relevant channel exogenous. Any deviation of the IRFs of the later model from IRFs of the former model represent the strength of each channel, i.e. the larger the deviation, the stronger or more important the particular channel.

\section{Empirical Results}

\subsection{Transmission from Central Bank Monetary Policy Changes to Interest Rates}

First, Table 3 reports the data descriptions and descriptive statistics for different interest rates used for the empirical analysis. The mean value of the short-term money market rate (3-month Treasury bill rate, TBR) is 13.21 per cent. It appears that on average, retail interest rates remain high and volatile in Sri Lanka. This could be due to high volatility in money market rates and the relatively high and volatile inflation rates as well as due to high risk premiums. ${ }^{18 /}$ In particular, lending rates in LCBs (for example, AWPR), which are linked to overnight interbank call money market rates, are more volatile. It is also noticed that deposit rates of LCBs (AWDR and AWFDR) remain below the TBR. Mean values suggest that LSBs offer high deposit rates (DRS) while charging high for lending (LRS). This high rate structure could be due to the nature of their business activity, for example, long term lending and due to the impact of higher non-performing assets in LSBs.

18/ It is generally observed that Sri Lankan banks operate with high net interest margins driven by individual bank's dominance in the market, cost structure, risk profile, ownership form, access to alternative funding sources, etc. (Perera, Skully, and Nguyen, 2012). 
Table 3: Data Description and Descriptive Statistics

This table presents descriptions and descriptive statistics of data for the period 1990:1-2012:12 used to model the transmission from central bank monetary policy changes to interest rates.

\begin{tabular}{|c|c|c|c|c|c|c|c|}
\hline \multirow{2}{*}{ Variable } & \multirow{2}{*}{$\begin{array}{c}\text { Variable } \\
\text { Code }\end{array}$} & \multirow{2}{*}{ Description } & \multicolumn{5}{|c|}{ Descriptive Statistics } \\
\hline & & & $\begin{array}{l}\text { No. of } \\
\text { Obs }\end{array}$ & Mean & $\begin{array}{l}\text { Std. } \\
\text { Dev. }\end{array}$ & Min. & Max. \\
\hline \multicolumn{8}{|c|}{ Panel A: Monetary Policy Indicator } \\
\hline Money market rate & TBR & 3-month Treasury bill rate & 276 & 13.21 & 4.07 & 6.97 & 21.30 \\
\hline \multicolumn{8}{|l|}{ Panel B: Different Interest Rates } \\
\hline \multicolumn{8}{|c|}{ LicensedCommercial Banks (LCBs) } \\
\hline Average lending rate & AWPR & Weighted average prime lending rate & 276 & 15.42 & 3.76 & 8.94 & 22.86 \\
\hline Average deposit rate & AWDR & Weighted average deposit rate & 276 & 10.05 & 3.07 & 4.84 & 19.40 \\
\hline Average fixed deposit rate ${ }^{1 /}$ & AWFDR & Weighted average fixed deposit rate & 193 & 11.20 & 2.76 & 6.82 & 16.92 \\
\hline \multicolumn{8}{|c|}{ LicensedSpecialised Banks (LSBs) } \\
\hline Average lending rate & LRS & Average lending rate for major $3 \mathrm{LSBS}$ & 276 & 16.91 & 3.16 & 11.33 & 22.17 \\
\hline Average deposit rate & DRS & Average fixed deposit rate for major 3 LSBs & 276 & 12.93 & 3.31 & 7.00 & 17.67 \\
\hline
\end{tabular}

1/ Available since 1997

Thereafter, stationary properties, co-integration and Granger causality of money market rates and retail interest rates are established as reported in Table 4. Based on the results presented in Panel A, at the levels, both ADF and PP tests do not reject the hypotheses that all interest rate series are unit root non-stationary, but all series are stationary at the first differences. Thus, all rates are found to be integrated of order one, i.e., I(1). Based on the Johansen's method, Panel B presents evidence for statistically significant long run relationships between money market and retail interest rates. Moreover, the results in Panel $\mathrm{C}$ confirm that money market rates Granger cause the retail interest rates and as expected, one-way causality is running from money market rates to retail rates. Unreported results confirm that policy interest rates (CBR) also have the same causality.

After having observed the co-integrating relationships between money market and retail interest rates, long and short run dynamics of IRPT are examined. The results are reported in Table 5. These results are obtained through estimating the long run model given in 


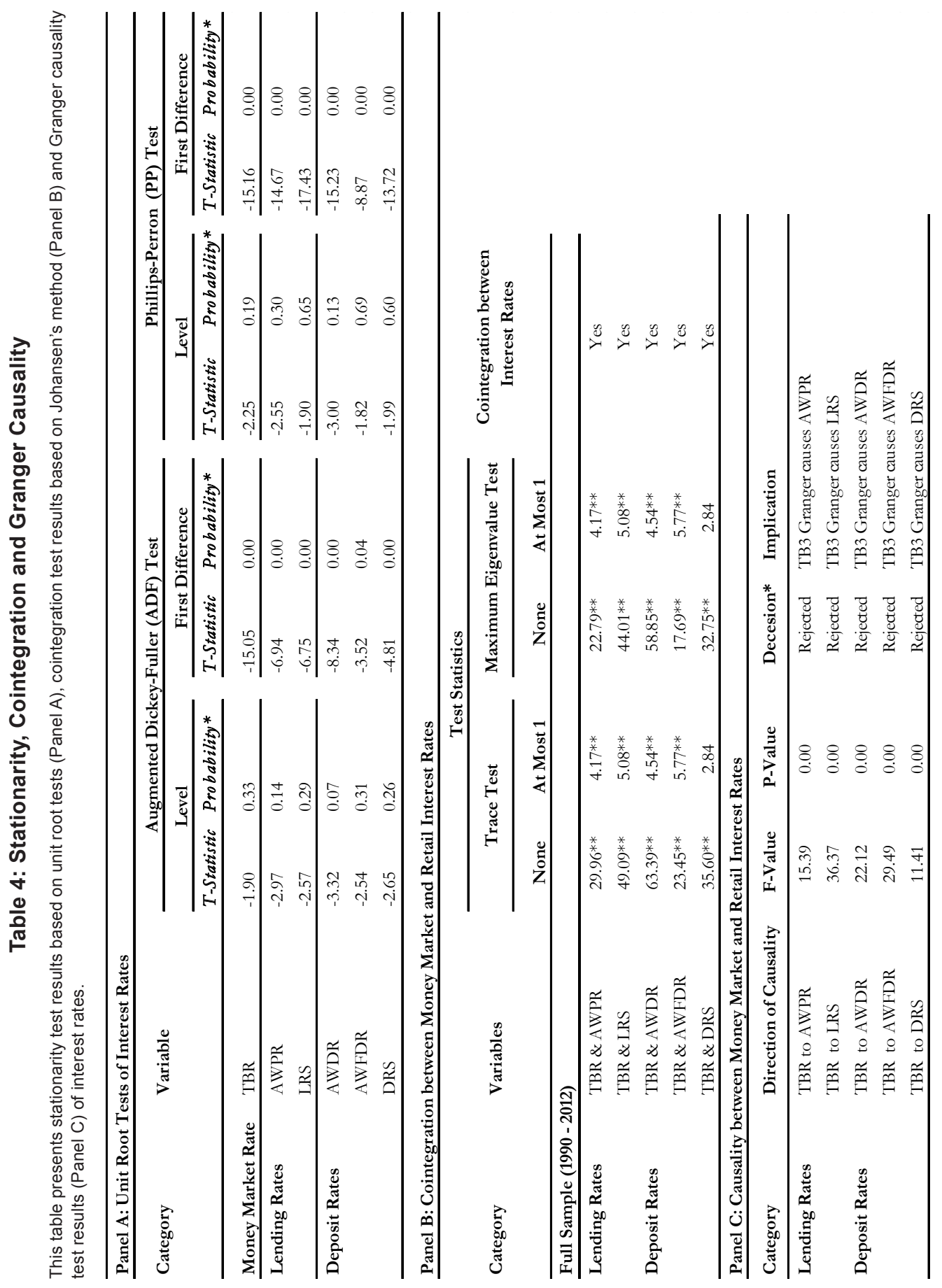




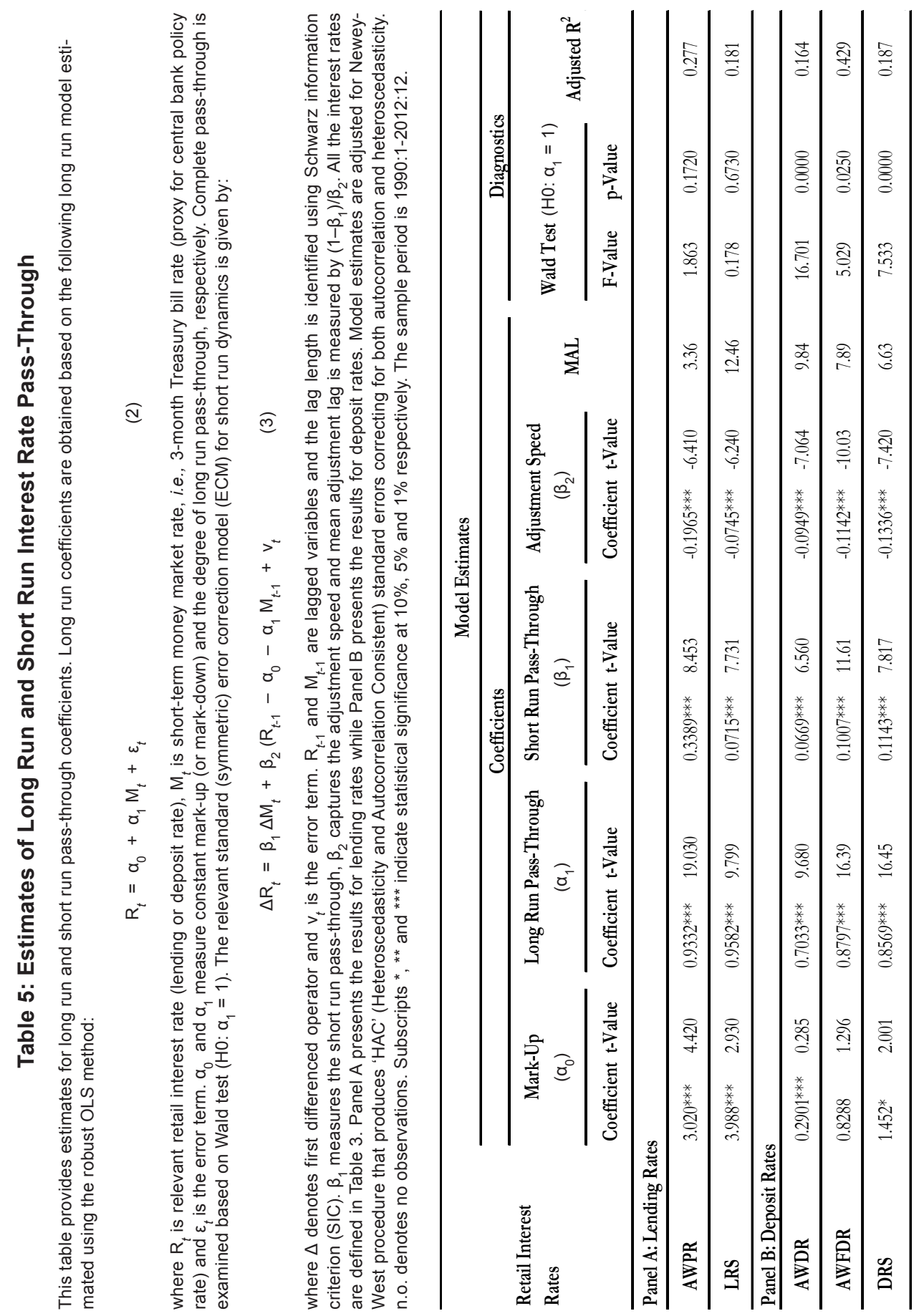


Eq. (2) and the error correction models given in Eq. (3). It is observed that models are broadly robust for diagnostics, but the long list of test results is not reported for brevity. ${ }^{19 /}$

According to the results in Table 5, somewhat higher mark-ups $\left(\alpha_{0}\right)$ are observed for lending rates. This indicates the riskiness of loans in comparison to deposits (Horváth and Podpiera, 2012) and this is consistent with similar studies of Chong et al. (2006) for Singapore, Liu et al. (2008) for New Zealand and Zulkhibri (2012) for Malaysia etc. Meanwhile, high and almost complete long run pass-through $\left(\alpha_{1}\right)$ is observed for lending rates of LCBs and LSBs (AWPR and LRS, respectively in Panel A). High pass-through in the AWPR could be due to several reasons. First, AWPR is mostly based on short-term loans of LCBs (such as credit granted for working capital needs or trade related activities) and are broadly linked to the changes in short-term money market rates. The higher response of AWPR to money market rates also suggests that monetary policy is quite effective at the shorter end of the yield curve (De Bondt, 2005; Liu et al., 2008).

Second, it indicates that short-term lending rates are much more competitive than the long-term lending and/or deposit rates. In particular, as argued by Bredin et al. (2002) in the context of Ireland, high IRPT could be due to the impact of borrowings by large corporations (generally prime customers). These firms have greater access to alternative financing that are unavailable for average customers encouraging the LCBs to fully and quickly adjust their prime lending rates. High pass-through in lending rates of LSBs (LRS) could be due to emerging competition in this sector. ${ }^{20 /}$ In contrast, relatively low or somewhat incomplete long run pass-through is observed for deposit rates (Panel B of Table 5). As De Bondt (2005) suggests in the case of European markets, this could be due to the existing uncompetitive forces and/or prevailing switching and asymmetric information costs in deposit markets in comparison to the lending markets.

Table 5 also reports the results for short run dynamics estimated using ECMs. ${ }^{21 /}$ Accordingly, lending rates of LCBs (AWPR) record the highest short run pass-through $\left(\beta_{1}\right)$ of about 34 per cent $\left(\beta_{1}=0.3389\right)$. Both lending rates of LSBs (LRS) and deposit rates of LCBs (AWDR) report low levels of short run pass-through of around 7 per cent ( $\beta_{1}=0.0715$ and 0.0669 , respectively). Meanwhile, error correction adjustments $\left(\beta_{2}\right)$ that

19/ Key diagnostics tests: Breusch-Godfrey serial correlation Lagrange multiplier test for serial correlation; Ramsey RESET test for functional form; skewness and kurtosis tests for residuals based on Jarque-Bera statistic for normality and White's heteroscedasticity test for homescedasticity are conducted based on Pesaran and Pesaran (1997); Brooks (2008). The results are available upon request.

20/ This is reflected in the declining market share of the National Savings Bank, which accounted for about more than 90 per cent of total LSB sector assets in 1997 and then declined to about 75 per cent by 2012.

21/ The optimal lag structure for the ECM is determined using Schwartz Information Criteria (SIC) and it suggests that lag of one period is sufficient for Sri Lanka, which is consistent across many studies in this nature [for example, Espinosa-Vega and Rebucci (2004); De Bondt (2005); Zulkhibri (2012), etc.]. 
represent the speed of adjustment are negative and statistically significant indicating the mean reversion of the interest rates toward long run equilibrium. While AWPR records the lowest MAL of 3.36 months indicating the faster adjustment, LRS reports the highest MAL of 12.46 months indicating the slowest adjustment. Hence, although long run IRPT for LSB lending rates is higher, short run adjustment remains sluggish, which could be due to high switching costs, adverse selection as well as due to moral hazard problems in these lending markets (Chong et al., 2006).

Taken together, on average, lending rates report the highest long run and short run pass-through, i.e., 95 per cent and 20 per cent, respectively. For deposit rates, the average long run pass-through is about 86 per cent and the short-run pass-through is about 10 per cent. ${ }^{22 /}$

To confirm the robustness of the above discussed results, the system equation approach is used. Accordingly, responses of retail interest rates to money market rate innovations are examined based on impulse response functions (IRF) within a VAR framework. As such, IRFs are estimated for 12 months for a shock standardised to equal a 1 per cent point (100 basis points) change in the money market rate. The instantaneous response shows how an unanticipated shock to the money market rate (TBR) is transmitted to retail rates within a month. The maximum response represents the maximum pass-through within a year.

Based on the results in Table 6, which reports the results for shocks, it is evident that lending rate pass-through is comparatively higher than the deposit rate pass-through. In particular, both instantaneous and maximum responses are higher for AWPR. Second, amongst the deposit rates, AWFDR records the highest long term pass-through.

Next, in order to observe whether interest rates adjustments are above or below their equilibrium levels, asymmetric rigidity is examined. Table 7 presents the results for both symmetric and asymmetric MALs obtained using the ECM estimates. These results broadly suggest that symmetric and asymmetric MALs are lower for lending rates. For example, Panel A of Table 7 confirms that both symmetric MAL and asymmetric MALs (MAL ${ }^{+}$and $\mathrm{MAL}^{-}$) remain less than 4 months for AWPR. This indicates that residual errors are lower for AWPR, and hence, they are linked with equilibrium values leading to improvements in MALs (Chong, 2010). Nevertheless, significant asymmetry is observed for lending rates in LSBs and especially for deposit rates.

22/ These results cannot be compared with some previous estimates for Sri Lanka due to the differences in selected interest rates and samples. For example, based on a sample for the regulated period, Cottarelli and Kourelis (1994) observe that short run pass-through is about 15 per cent from discount rates to lending rates. Based on a sample for 1996-2004, Amarasekara (2005) finds that long run pass-through to prime lending rates from call money rates is about 50 per cent. 


\section{Table 6: VAR Estimates of Interest Rate Pass-Through}

This table provides estimates for instantaneous and long run interest rate pass-through based on the impulse response functions by estimating a VAR model given by the following representation:

$$
\begin{aligned}
& Y_{t}=c+\sum_{i=1}^{n} A_{i} Y_{t-1}+\varepsilon_{t} \\
\text { with: } & Y_{t}=\left[\begin{array}{l}
\mathrm{R} \\
\mathrm{M}
\end{array}\right]_{t}
\end{aligned}
$$

where $Y_{t}$ is a vector of endogenous and exogenous variables and $i$ is optimal lag length decided by SIC. $R_{t}$ is relevant retail interest rate, i.e., 3-month Treasury bill rate (lending or deposit rate), $M_{t}$ is short-term money market rate (proxy for central bank policy rate, i.e., TBR), $\varepsilon_{t}$ is error term. Following Choleski decomposition, impulse response functions are estimated for a period of 12 months for a shock standardised to equal a 1 per cent point (100 basis points) change in the money market rate to examine instantaneous and the maximum responses. * Maximum response is the largest response within 12-month period in the same direction as the movement in the money market rate following the innovation. The sample period is 1990:1-2012:12.

Retail Interest Rates / Impulse Response

Coefficient

Panel A : Lending Rates

AWPR

Instantaneous

0.32

Maximum Response

0.90

LRS

$\begin{array}{ll}\text { Instantaneous } & 0.03\end{array}$

$\begin{array}{ll}\text { Maximum Response } & 0.84\end{array}$

Panel B : Deposit Rates

AWPR

$\begin{array}{ll}\text { Instantaneous } & 0.03\end{array}$

$\begin{array}{ll}\text { Maximum Response } & 0.41\end{array}$

\section{AWFDR}

Instantaneous

Maximum Response

0.72

DRS

Instantaneous

Maximum Response

0.49 
Table 7: Symmetric and Asymmetric Mean Adjustment Lags

This table provides symmetric and asymmetric mean adjustment lags (MALs), estimated using the coefficients derived based on Eq. (4) and Eq. (6) - Eq. (7). Panel A present results for individual rates and Panel B present results for averages. The sample period is 1990:1-2012:12.

\begin{tabular}{lccc}
\hline \multirow{2}{*}{ Retail Interest Rates } & Symmetric Model & \multicolumn{2}{c}{ Asymmetric Model } \\
\cline { 2 - 4 } & MAL & MAL $^{+}$ & MAL $^{-}$ \\
\hline Panel A : Lending Rates & & & \\
\hline AWPR & 3.36 & 3.47 & 3.33 \\
LRS & 12.46 & 10.52 & 14.14 \\
\hline Panel B : Deposit Rates & & & \\
\hline AWDR & 9.84 & 7.52 & 8.59 \\
AWFDR & 7.89 & 7.51 & 6.52 \\
DRS & 6.63 & 6.81 & \\
\hline Panel C : Averages & & & 10.73 \\
\hline \multicolumn{1}{c}{ Lending Rates } & 7.91 & 7.00 & \\
Deposit Rates & 8.12 & 7.28 & \\
\hline
\end{tabular}

To that end, these results suggest that asymmetric adjustments continue to exist in the Sri Lankan context. For example, it is observed that both symmetric and asymmetric MALs are lower for lending rates relative to the deposit rates indicating faster adjustments in AWPR. However, similar adjustments are not observed for other interest rates. As observed in the prior empirical studies for other countries, for example, Chong (2010), such asymmetry could continue to exist due to the oligopolistic structure of the banking market and due to bank market power.

\subsection{Transmission from Market Interest Rates to Target Variables through Different Channels}

First, Figure 2 depicts the behaviour of the variables used for VAR and SVAR models based on quarterly seasonally adjusted data for the period March 1996 to December 2012. Since these figures are self-explanatory, a detailed discussion is not provided. 
Figure 2: Plots of Data Series - Quarterly VAR and SVAR Models

SRI_GDP

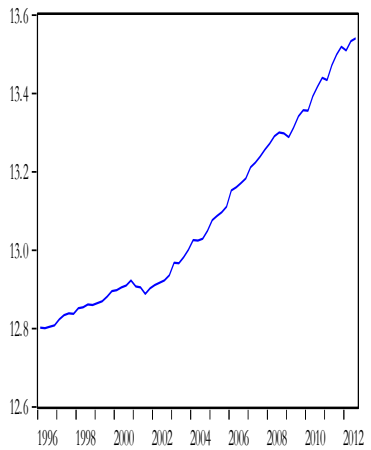

SR__MNR

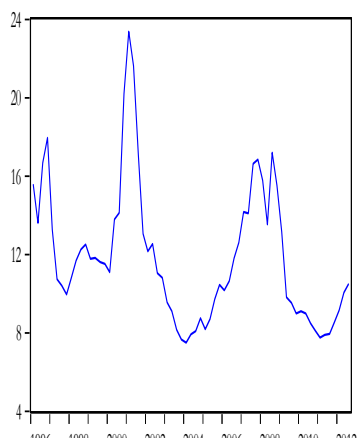

$\begin{array}{lllllllll}1096 & 1908 & 2000 & 2002 & 2004 & 2006 & 2008 & 2010 & 2012\end{array}$

SR_EXR

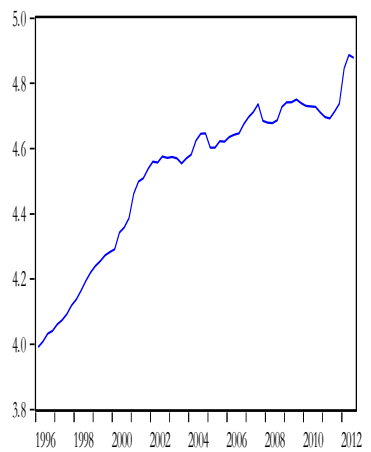

SRICPI

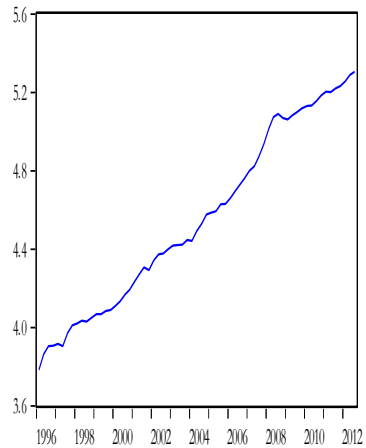

SRI_RLOAN

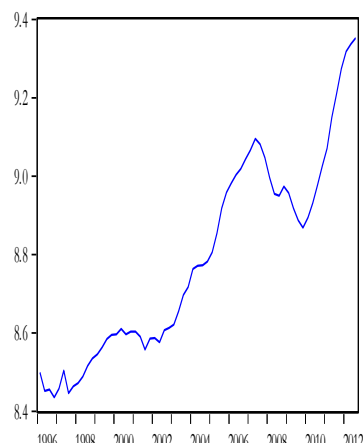

COMP

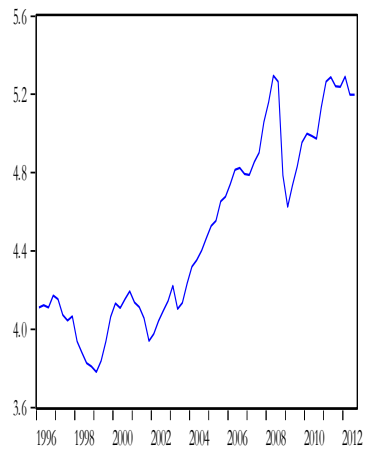

SR_MI

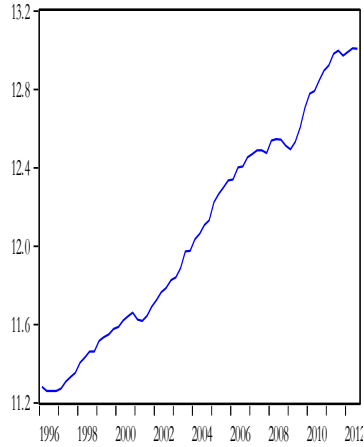

SRISMII

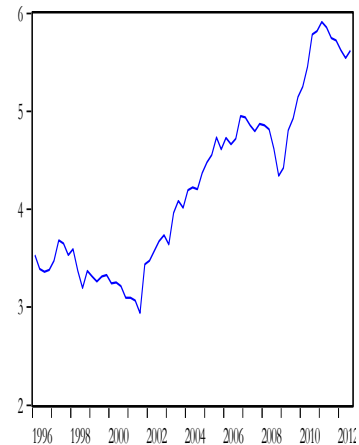

FEDR

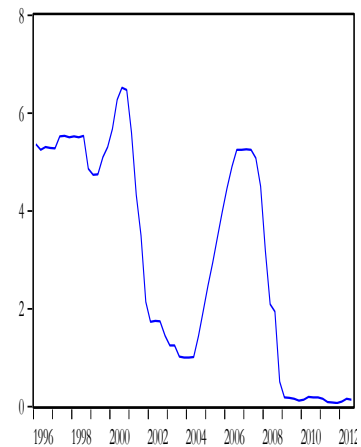


As a benchmark model for monetary transmission, first, an unrestricted VAR model is estimated. This benchmark model (Eq. 8) includes real output $\left(G D P_{t}\right)$, consumer prices $\left(C P I_{t}\right)$, a monetary aggregate $\left(M l_{t}\right)$ and the short-term interbank money market rate $\left(M M R_{t}\right) .{ }^{23 /}$ Having established a baseline VAR model, then, impulse response functions (IRFs) are calculated and presented in Figure 3.

\section{Figure 3: Impulse Response Functions (Baseline VAR Model)}

Response to Cholesky One S.D. Innovations \pm 2 S.E.
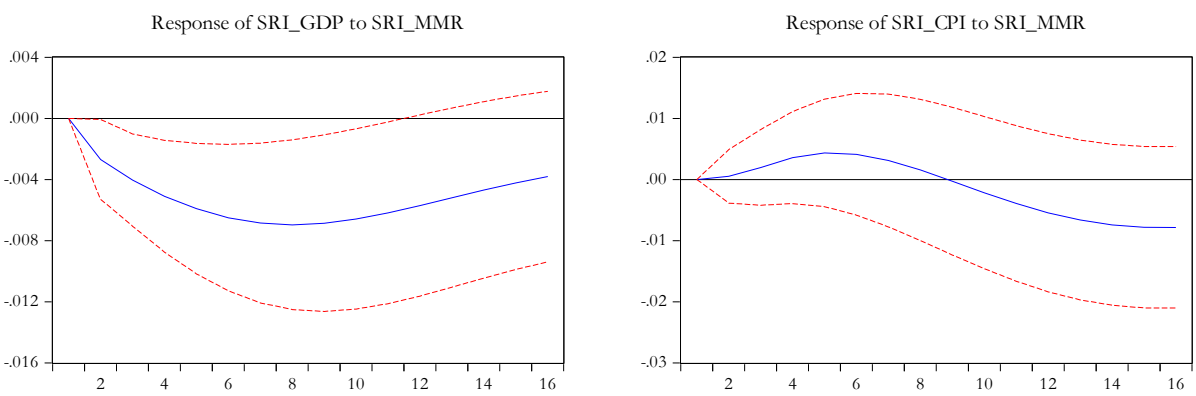

Response of SRI_M1 to SRI_MMR
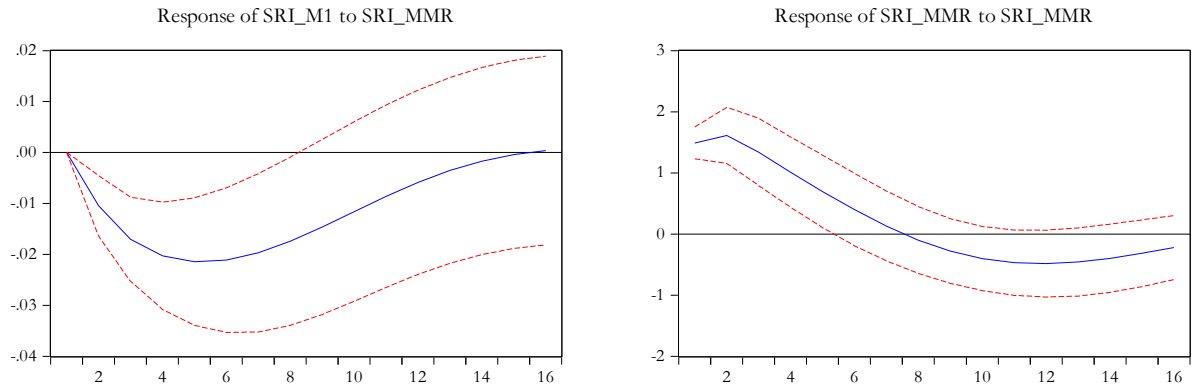

23/ Unreported unit root (ADF and PP) tests and the Johansen cointegration test results suggest that interest rate is $\mathrm{I}(0)$, whilst all the other variables are $\mathrm{I}(1)$ and that there are four cointegrating vectors in the VAR system. Hence, it confirms the appropriateness of the strategy suggested by Sims et al. (1990) and Lütkepohl and Reimers (1992) to estimate the VAR in levels despite the fact that series are integrated. Therefore, estimates of the models are carried out in levels. The optimal lag length under different information criteria (Schwarz and Hannan-Quinn criteria) appears to be one. However, one lag is too short to capture underlying dynamics of the system while it could run into the degrees of freedom problem if many lags are included (Disyatat and Vongsinsirikul, 2003). Moreover, in the case of SVAR, it could pose a risk of over-parameterisation. Also, a lag order of one may lead to autocorrelation in the residuals and more lags tend to show greater variability in impulse responses. As such, guided by prior literature, VAR models are estimated with two lags. Relevant VAR models are also tested for stability, no serial correlation and the absence of heteroskedasticity. As suggested by these unreported results, estimated VAR model appears broadly valid. These results are available upon request. 
As shown in Figure 3, first, an unexpected rise in short-term interest rates causes a statistically significant decline in real output (SRI_GDP). In particular, an unexpected tightening of monetary policy gives rise to a U-shaped output response that bottoms-out after 6-8 quarters. The relatively quicker response in output to a monetary contraction is consistent with the observations in prior research, for example, Leeper et al. (1996) and Berument and Froyen (2006) for US, Disyatat and Vongsinsirikul (2003) for Thailand, Arin and Jolly (2005) for Australia and New Zealand, etc. Second, consumer prices (SRI_CPI) initially report a positive reaction to an interest rate innovation showing a 'price puzzle'. ${ }^{24}$ Third, following an interest rate shock, monetary aggregates (SRI_M1) react immediately, which is consistent with the evidence reported in Leeper et al. (1996); Kim and Roubini (2000); Sousa and Zaghini (2007); Ito and Sato (2008) and Rafiq and Mallick (2008). In fact Leeper et al. (1996) describe a similar monetary contraction as a strong liquidity effect: money contracts quickly and stays persistently below average following an interest rate jump that is itself persistent. According to Figure 3, the effect on M1 bottoms out by the fourth quarter and starts dissipating. Finally, the interest rate shock (SRI_MMR) is quite persistent and starts returning to its initial levels after about seven quarters. As expected, the shock results in a considerable initial increase, with the short-term money market rate actually peaking after two quarters and a subsequent steady decline. It continues to decline below the initial level and reaches the lowest point by 11-12 quarters after the shock, and then begins to increase towards the base level.

In order to examine the contributions to fluctuations in a given variable caused by different shocks, variance composition (VD) for each variable at forecast horizons of one through to four years is examined. These results are presented in Table 8 .

According to the results, output (SRI_GDP) indicates that after four years (16 quarters), interest rate shocks account for about 31 per cent of the fluctuation in output, with own shocks accounting for most of the rest. This is consistent with prior studies indicating that interest rate innovations lead to long run fluctuations in economic activity. Meanwhile, VD for prices (SRI_CPI) indicates that after four years (16 quarters), money accounts for 41 per cent of the fluctuation in prices while own shocks account for more than 50 per cent of the variance. Interest rate innovations alone account only for about 5 per cent after

24/ In the VAR systems, positive orthogonalised shocks to central bank policy rates are related to a protracted rise in the price levels suggesting that some inflation indicator is missing from the VAR (Laopodis, 2013). This is well known as 'price puzzle', i.e., prices increase following an interest rate tightening (Sims, 1992; Leeper et al., 1996; Kim and Roubini, 2000). Sims (1992) suggests that the price puzzle might be due to the fact that interest rate innovations partly reflect inflationary pressures leading to price increases and also states as the failure to include a rich enough specification of the information available to policy makers. This is quite common in similar empirical literature. For example, Dale and Haldane (1995) for UK, Leeper et al. (1996) for the US, Morsink and Bayoumi (2001) for Japan, Disyatat and Vongsinsirikul (2003) for Thailand, Arin and Jolly (2005) for Australia and New Zealand, etc., report similar positive responses in prices. 
Table 8: Variance Decomposition (Baseline VAR Model)

This table presents forecast error variance decomposition of output (SRI_GDP), prices (SRI_CPI), narrow money (SRI_M1) and short-term interest rate (SRI_MMR) for the baseline VAR model. Cholesky Ordering: SRI_GDP SRI_CPI SRI_M1 SRI_MMR. Period is given by number of quarters.

\begin{tabular}{llllll}
\hline \multicolumn{7}{l}{ Variance Decomposition of SRI_GDP: } & & & \\
\hline Period & S.E. & SRI_GDP & SRI_CPI & SRI_M1 & SRI_MMR \\
\hline & & & & & \\
1 & 0.0109 & 100.0 & 0.00 & 0.00 & 0.00 \\
2 & 0.0145 & 94.90 & 0.02 & 1.60 & 3.48 \\
3 & 0.0176 & 88.99 & 0.24 & 3.13 & 7.64 \\
4 & 0.0203 & 82.96 & 0.41 & 4.56 & 12.07 \\
5 & 0.0227 & 77.33 & 0.46 & 5.81 & 16.41 \\
6 & 0.0249 & 72.22 & 0.41 & 6.89 & 20.48 \\
7 & 0.0269 & 67.69 & 0.35 & 7.86 & 24.10 \\
8 & 0.0286 & 63.73 & 0.39 & 8.74 & 27.14 \\
9 & 0.0302 & 60.29 & 0.61 & 9.57 & 29.53 \\
10 & 0.0316 & 57.24 & 1.09 & 10.40 & 31.27 \\
11 & 0.0329 & 54.50 & 1.89 & 11.24 & 32.37 \\
12 & 0.0342 & 51.95 & 3.02 & 12.13 & 32.90 \\
13 & 0.0353 & 49.53 & 4.47 & 13.07 & 32.94 \\
14 & 0.0365 & 47.17 & 6.18 & 14.09 & 32.56 \\
15 & 0.0376 & 44.85 & 8.09 & 15.18 & 31.88 \\
16 & 0.0388 & 42.55 & 10.13 & 16.36 & 30.96 \\
& & & & &
\end{tabular}

\begin{tabular}{llllll}
\multicolumn{6}{l}{ Variance } \\
\hline Pecomposition of SRI_M1: & S.E. & SRI_GDP & SRI_CPI & SRI_M1 & SRI_MMR \\
\hline & & & & & \\
1 & 0.0238 & 1.96 & 0.03 & 98.01 & 0.00 \\
2 & 0.0359 & 2.31 & 1.65 & 87.54 & 8.50 \\
3 & 0.0471 & 1.73 & 1.73 & 78.56 & 17.99 \\
4 & 0.0569 & 1.23 & 1.84 & 71.83 & 25.11 \\
5 & 0.0652 & 0.95 & 2.35 & 66.78 & 29.93 \\
6 & 0.0723 & 0.87 & 3.45 & 62.85 & 32.83 \\
7 & 0.0786 & 0.96 & 5.24 & 59.70 & 34.10 \\
8 & 0.0842 & 1.18 & 7.73 & 57.07 & 34.02 \\
9 & 0.0893 & 1.48 & 10.85 & 54.77 & 32.90 \\
10 & 0.0942 & 1.82 & 14.41 & 52.69 & 31.08 \\
11 & 0.0991 & 2.18 & 18.16 & 50.78 & 28.88 \\
12 & 0.1039 & 2.54 & 21.85 & 49.05 & 26.56 \\
13 & 0.1088 & 2.86 & 25.27 & 47.53 & 24.34 \\
14 & 0.1137 & 3.16 & 28.27 & 46.26 & 22.30 \\
15 & 0.1186 & 3.44 & 30.80 & 45.27 & 20.49 \\
16 & 0.1235 & 3.70 & 32.84 & 44.55 & 18.91
\end{tabular}

\begin{tabular}{llllll}
\multicolumn{7}{l}{ Variance Decomposition of SRI_CPI: } \\
\hline Period & S.E. & SRI_GDP & SRI_CPI & SRI_M1 & SRI_MMR \\
\hline & & & & & \\
2 & 0.0186 & 0.43 & 99.57 & 0.0000 & 0.00 \\
3 & 0.0285 & 0.41 & 97.94 & 1.62 & 0.03 \\
4 & 0.0360 & 0.46 & 95.40 & 3.83 & 0.32 \\
5 & 0.0421 & 0.48 & 92.24 & 6.33 & 0.95 \\
6 & 0.0474 & 0.49 & 88.72 & 9.21 & 1.59 \\
7 & 0.0521 & 0.48 & 85.06 & 12.52 & 1.94 \\
8 & 0.0564 & 0.45 & 81.36 & 16.24 & 1.95 \\
9 & 0.0604 & 0.41 & 77.62 & 20.19 & 1.77 \\
10 & 0.0641 & 0.37 & 73.87 & 24.18 & 1.57 \\
11 & 0.0677 & 0.33 & 70.17 & 27.98 & 1.51 \\
12 & 0.0713 & 0.32 & 66.61 & 31.40 & 1.67 \\
13 & 0.0749 & 0.35 & 63.29 & 34.32 & 2.04 \\
14 & 0.0785 & 0.43 & 60.30 & 36.70 & 2.57 \\
15 & 0.0822 & 0.56 & 57.71 & 38.56 & 3.17 \\
16 & 0.0858 & 0.76 & 55.56 & 39.94 & 3.73 \\
\hline
\end{tabular}

\begin{tabular}{llllll}
\multicolumn{6}{l}{ Variance } \\
\hline Period & S.E. & SRI_GDP & SRI_CPI & SRI_M1 & SRI_MMR \\
\hline & & & & & \\
1 & 1.541 & 0.76 & 1.36 & 4.40 & 93.48 \\
2 & 2.307 & 0.35 & 5.77 & 3.39 & 90.49 \\
3 & 2.710 & 0.38 & 7.06 & 2.50 & 90.06 \\
4 & 2.907 & 0.61 & 6.74 & 2.35 & 90.30 \\
5 & 3.003 & 0.89 & 6.32 & 2.82 & 89.97 \\
6 & 3.055 & 1.16 & 6.53 & 3.68 & 88.63 \\
7 & 3.096 & 1.35 & 7.52 & 4.69 & 86.45 \\
8 & 3.144 & 1.45 & 9.02 & 5.57 & 83.96 \\
9 & 3.202 & 1.47 & 10.64 & 6.18 & 81.72 \\
10 & 3.266 & 1.44 & 12.02 & 6.47 & 80.07 \\
11 & 3.328 & 1.39 & 13.01 & 6.51 & 79.10 \\
12 & 3.382 & 1.34 & 13.58 & 6.41 & 78.67 \\
13 & 3.423 & 1.32 & 13.82 & 6.27 & 78.59 \\
14 & 3.451 & 1.32 & 13.85 & 6.17 & 78.65 \\
15 & 3.468 & 1.34 & 13.80 & 6.14 & 78.72 \\
16 & 3.477 & 1.37 & 13.73 & 6.19 & 78.71 \\
\hline
\end{tabular}

four years (16 quarters). Overall, the results of the baseline VAR model (both IRFs and VD analyses) confirm that an unanticipated monetary policy shock given by an interest rate shock causes reductions in output and prices.

Next, the validity of the baseline VAR results is investigated using the SVAR model. This is estimated based on the 'A_B approach' of Amisano and Giannini (1997) and the detailed estimates are reported in Table A.1 in Appendix II. The Likelihood Ratio (LR) test is used to examine over-identification restrictions of the model. According to the results of LR test presented in the same table, the validity of over-identification restrictions cannot be rejected at the standard significance level. The contemporaneous coefficients presented in this table provide some information regarding the importance of particular variables 
and the restrictions in the VAR system. However, they do not provide information about the dynamic relationships between the variables. Prior literature, for example, Leeper et al. (1996); Elbourne (2008); Li, İşcan and Xu (2010), among others, relies on dynamic responses to structural shocks in order to identify the effects and to gauge the effectiveness of monetary policy innovations. Accordingly, IRFs (structural innovations) obtained from SVAR estimates are used to identify monetary policy effects and the key responses are presented in Figure 4. It suggests that the SVAR model is a satisfactory description of MTM in Sri Lanka and provides an adequate explanation of the theoretical underpinnings. As per structural innovations, a monetary policy shock represented by a one-standard deviation innovation to money market rate (Shock 6 of the SVAR model) has the following effects.

Figure 4: Structural Innovations (Impulse Response Functions) of the SVAR Model

Response to Structural One S.D. Innovations - Interest Rate Shock (Shock 6)

Response of SRI_GDP

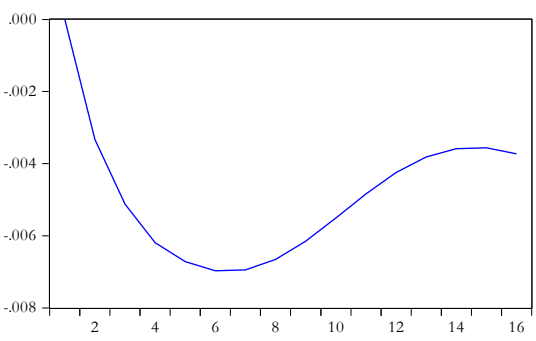

Response of SRI_M1

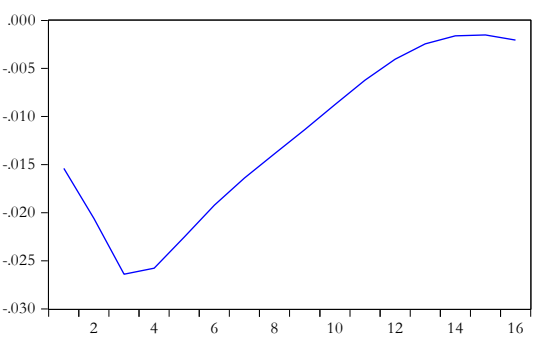

Response of SRI_CPI

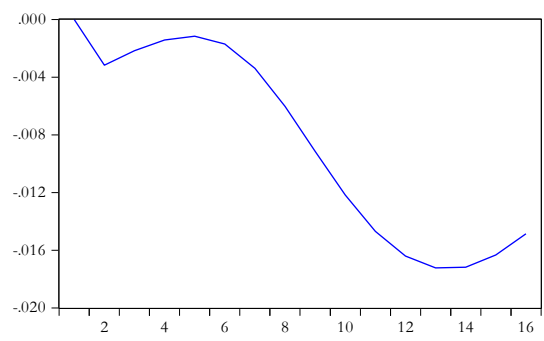

Response of SRI_EXR

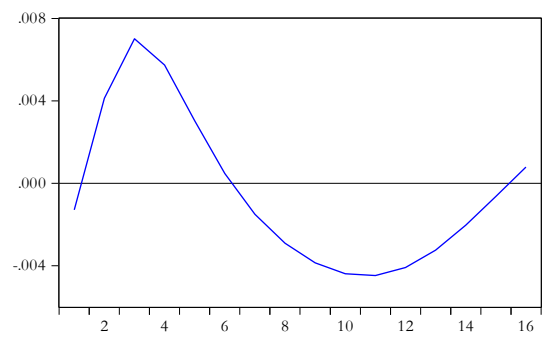


First, the target variable output (SRI_GDP) responds by the second quarter. The relatively immediate decline in output is consistent with prior research like Kim and Roubini (2000) for UK and Canada, Dungey and Pagan (2000); Berkelmans (2005) and Fraser, Macdonald and Mullineux (2012) for Australia, Li et al. (2010) for US and Canada, Sousa and Zaghini (2007) for G-5 countries, etc. Roughly after 6-7 quarters, the impact on output starts reversing and thus moves up towards the base. Second, after a monetary contraction, despite there remaining a marginal reversal during the first year, price levels (SRI_CPI) decline persistently to reach a maximum of about 1.5 per cent to a 1 per cent increase in interest rates by the 12th quarter. Again, this observation is consistent with prior literature [for example, Dungey and Pagan (2000) for Australia, Kim and Roubini (2000) for Italy, Elbourne (2008) for UK, Ito and Sato (2008) for Thailand and Philippines]. Importantly, structural innovations indicate that the price puzzle is weaker and the impact of monetary policy on prices is persistent although it starts dissipating in the long run.

Third, as in Leeper et al. (1996) for US and Kim and Roubini (2000) for UK, monetary aggregates (SRI_M1) respond to monetary policy shock showing some liquidity effect. ${ }^{25 /}$ Fourth, the exchange rate (SRI_EXR) indicates some initial increase, but the effect is relatively short-lived. This suggests that after an unexpected shock to interest rates, nominal exchange rates quickly depreciate for up to 2-3 quarters, indicating some evidence for an exchange rate puzzle though it starts appreciating from about the sixth quarter. These observations also correspond with similar research for small open economies. For example, Fraser et al. (2012) observe that in the presence of a monetary policy shock, exchange rate rises initially, but the effect is relatively short-lived. Kim and Roubini (2000) also show that initial increase in the exchange rate (depreciation) is justifiable in a VAR model for an open economy. In the context of Indonesia, Afandi (2005) argues that an increase in the domestic interest rate often follows exchange rate depreciation in an attempt to sterilise the expansionary effect of central bank intervention in the foreign exchange market. A similar scenario can also be observed in Sri Lanka as exchange rates tend to depreciate during periods of monetary tightening, which can be considered as a situation of reverse causality.

Overall, the results of the SVAR model for Sri Lanka show that both output and prices respond negatively to an unanticipated rise in interest rates (monetary contraction) and the price reaction appears strong and persistent. Hence, the results suggest that monetary policy is quiet effective to affect target variables of the central bank. To that end, any output puzzle (increase in output in response to a contractionary monetary shock) is not observed and there is substantial reduction in the price puzzle. Moreover, a liquidity

25/ When the effect is not persistent, it can be argued that central bank actions do not have direct and persistent effects on monetary aggregates (Duguay, 1994). 
puzzle (increase in monetary aggregate in response to a contractionary monetary shock) cannot be observed, but an exchange rate puzzle (exchange rate depreciates in response to a contractionary monetary shock) exists.

These results are quiet robust for alternative SVAR models, which are not reported to preserve space. Amongst them, for example, the results of an alternative SVAR model that includes variables such as industrial production index (IPI), a broad money aggregate (M2), nominal effective exchange rates (NEER) are broadly compatible with the above discussed (7-variable) SVAR model. This consistency can be observed through the structural innovations presented in Figure 5. To that end, it is evident that monetary transmission in Sri Lanka is well explained by the standard 7-varibale SVAR model suggested by Kim and Roubini (2000) in the context of advanced countries.

Figure 5: Comparison of 7-Variable SVAR and Alternative SVAR Models
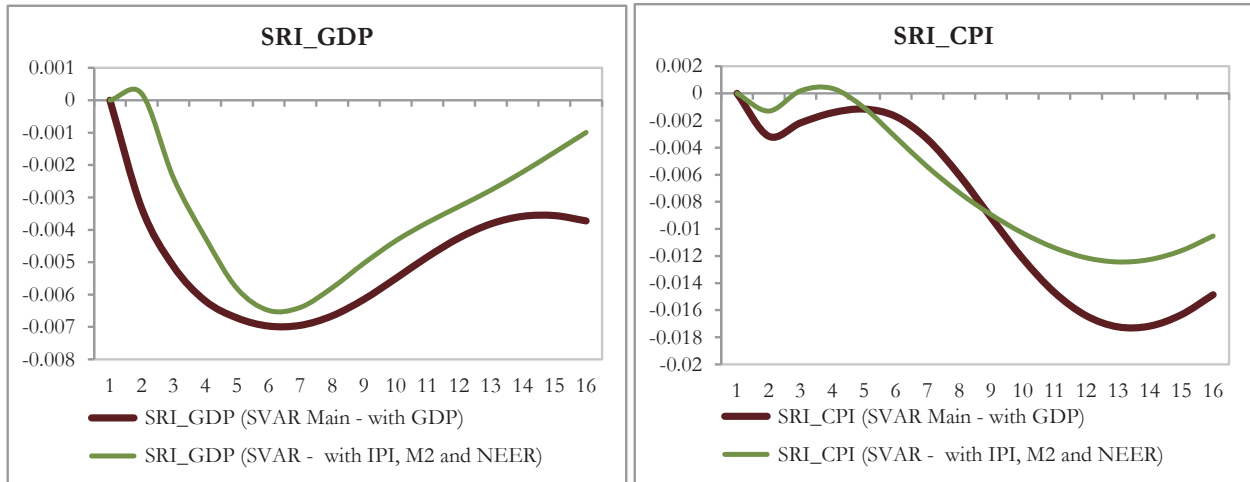

Meanwhile, forecast error variance decompositions (VD) for each variable up to four years is calculated to identify the fluctuations in the target variables. As per VD values presented in Table A.2 in Appendix II, first, except for the own shock, in the short run (around the second quarter), the highest source of variance in output (SRI_GDP) comes from the global commodity prices (Shock 1). In the period commencing from about 4th-5th quarter, the observable variation in the GDP is explained by money shock (Shock 5). However, as observed by Dale and Haldane (1995) and Elbourne (2008) for the UK, the impact of money is not substantially high as it only accounts for about 13 per cent of total GDP variation. In the long run, exchange rate shocks (Shock 7) dominate the variation in GDP. Second, similar to the observations of Ito and Sato (2008), in the short run, commodity price shocks (Shock 1) appear to be the main source of fluctuations in prices apart from its own shock. After about four quarters, innovations in both money and exchange rates (Shock 5 and 7, respectively) dominate price variations. In particular, 
consistent with some similar studies, for example, Morsink and Bayoumi (2001) for Japan, money shock (Shock 5) continues to dominate even in the 16th quarter confirming that money is the main source of long run price dynamics. Moreover, similar to Ito and Sato (2008) for Indonesia, Korea, Thailand, and the Philippines, it is observed that exchange rate shock (Shock 7) is an important determinant in the fluctuations of prices. Although, interest rate shocks (Shock 6) remain modest and the maximum impact seems to be about 12 per cent of the total price variation by about 9th quarter, its impact remains broadly persistent over the time horizon. Again, the evidence is consistent with the results of Ito and Sato (2008).

Next, in order to gauge the relative importance of different channels in transmitting monetary policy shocks in Sri Lanka, the baseline VAR model is appended using relevant variables that capture particular channels. First, to identify the bank lending channel, the baseline VAR model is appended using log of real bank credit $\left(R L O A N_{t}\right)$. As such, the appended VAR model comprises of $G D P_{t}, C P I_{t}, M 1_{t}, R L O A N_{t}$ and $M M R_{t}$. Based on the shut-down method, Figure 6 presents IRFs for the relative importance of the bank lending channel. In the calculation of IRFs, bank loans are exogenised (blocked-off).

\section{Figure 6: Comparison of VAR Models with Bank Lending Endogenous and Exogenous}
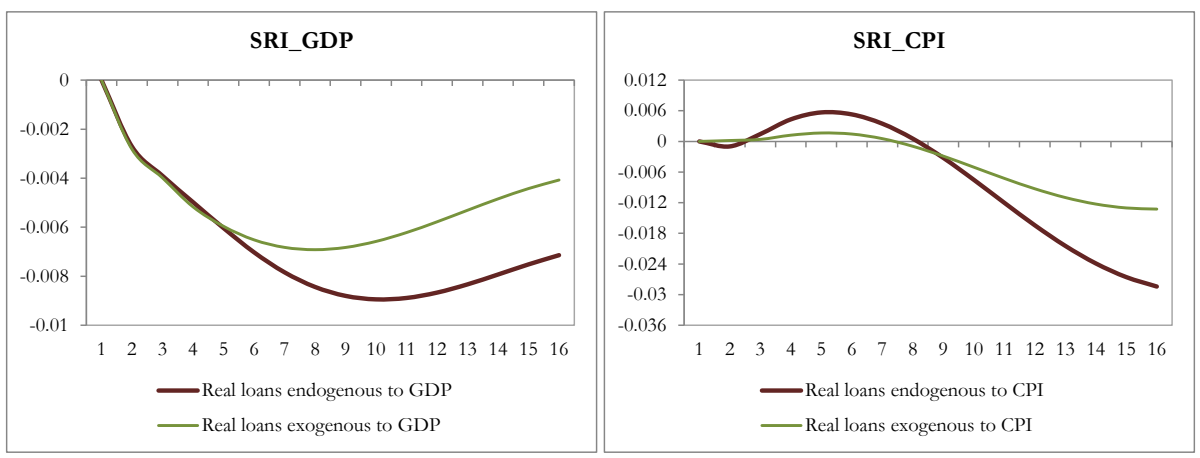

The output response (SRI_GDP) to an interest rate shock with and without real bank loans exogenised is broadly similar during the first five quarters. However, during the latter part of the time horizon, a notable difference is observed. In particular, it is evident that output response is clearly dampened when the role of bank loans is blocked-off. Similarly, the impact of interest rate shock is much pronounced for prices (SRI_CPI) when the bank loans are endogenous in comparison to the shock when bank loans are blocked-off. To that end, it appears that monetary policy in Sri Lanka is also transmitted via bank 
credit. Existence of a significant bank lending channel in the Sri Lankan context seems to be justifiable due to heavy reliance on bank credit as a main source of funding in Sri Lanka. This is a common feature for many emerging market economies (Cole, Moshirian, and $\mathrm{Wu}, 2008)$.

Second, the importance of the exchange rate channel is assessed by augmenting the baseline VAR model with the log of nominal exchange rate $\left(E X R_{t}\right)$ and hence the relevant VAR model comprises $G D P_{t}, C P I_{t}, M 1_{t}, M M R_{t}$ and $E X R_{t} \cdot{ }^{26 /}$ Figure 7 depicts the reaction of output and prices to innovations in interest rates with and without the nominal exchange rate exogenised. With the exchange rate channel blocked-off, output (SRI_GDP) and price (SRI_CPI) responses appear somewhat dampened. For example, trough output is lower in the exogenous model than the case when the exchange rate is endogenous. This suggests that the endogenous presence of the nominal exchange rate magnifies the effect of a monetary policy shock.

\section{Figure 7: Comparison of VAR Models with Exchange Rate Endogenous and Exogenous}
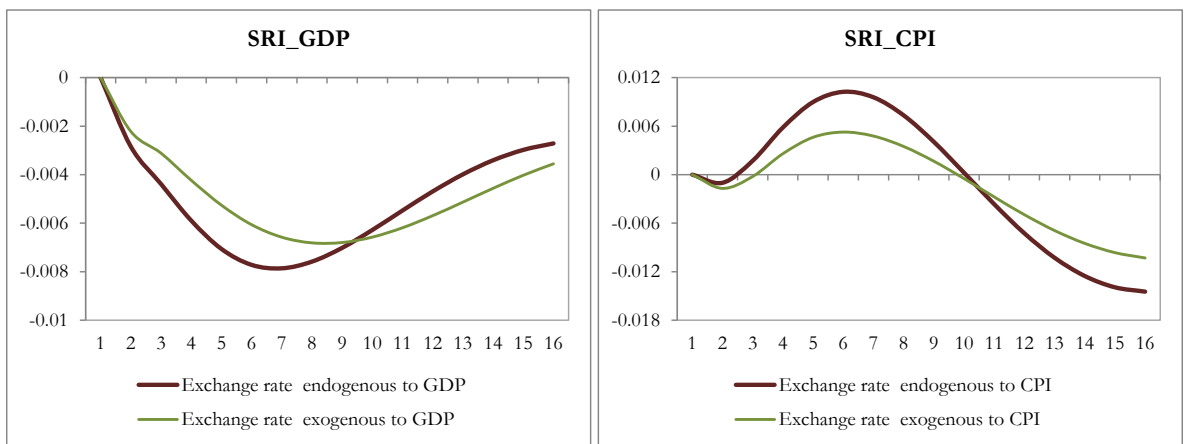

Disyatat and Vongsinsirikul (2003) suggest that evidence related to the exchange rate channel should be viewed with some caution. This is because modifications to the exchange rate system and regime changes could have implications on the non-linear movements in exchange rates. To examine this, the relevant VAR model is re-estimated excluding the impact of the fixed exchange rate regime (period prior to 2001 with the managed floating system) expecting that a move towards a more liberalised exchange rate regime will enhance the effects of monetary policy as monetary policy is subordinate to maintenance

26/ Inclusion of nominal exchange rate in the VAR system is consistent with prior studies, for example, Dale and Haldane (1995); Arin and Jolly (2005); Elbourne and de Haan (2006). 
of the exchange rate in a fixed regime. ${ }^{27 /}$ Also, it can be expected that a move from a fixed to a floating exchange rate regime would enhance the importance of the exchange rate channel for the reason that nominal exchange rates are not allowed to fluctuate in the former case. However, as per unreported results, blocking-off the exchange rate channel does not greatly dampen the impact of monetary policy. To that end, it can be concluded that exclusion of the data for the managed exchange rate period does not increase the significance of the exchange rates in propagating monetary shocks. This may be suggesting the impact of the exchange rate management policy of the CBSL.

Third, the propagation of monetary policy shocks via asset prices is examined. Accordingly, the baseline VAR model is appended to include the log of stock market index $\left(S M I_{t}\right)$. The significance of the asset prices in transmitting monetary policy shocks can be clearly examined by exogenising asset prices on the calculation of IRFs as in Figure 8.

Figure 8: Comparison of VAR Models with Asset Prices Endogenous and Exogenous

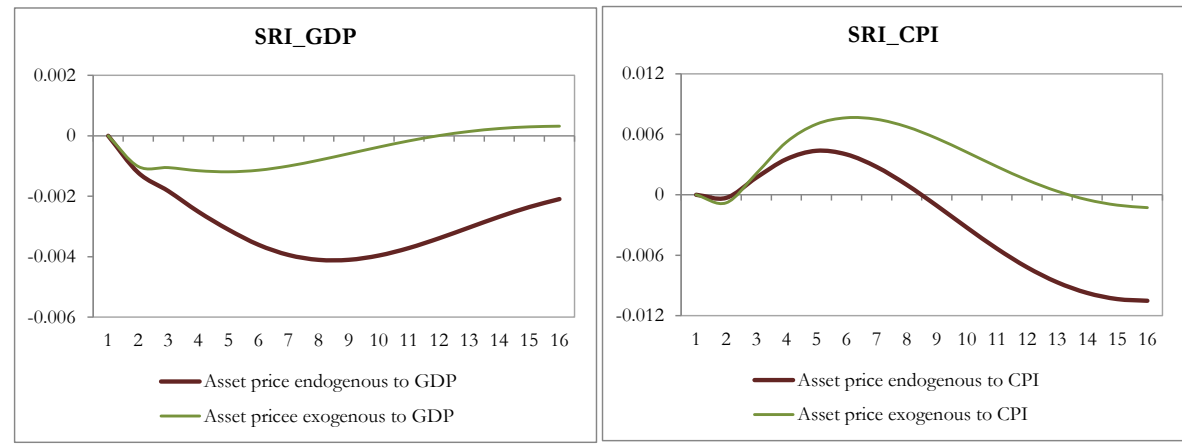

It is observed that exogenising of asset prices significantly dampens the response of output (SRI_GDP) and prices (SRI_CPI) indicating an existence of an asset price channel. In particular, although a significant deviation is not observed between endogenised and exogenised responses for the first 2-3 quarters, a notable difference is observed from about the fourth quarter. It is a common feature that the asset price channel is gradually gaining much importance in emerging market economies in propagating monetary policy shocks (Disyatat and Vongsinsirikul, 2003). An existence of an asset price channel in

27/ For an open economy operating with a fixed exchange rate regime, there is little scope for independent conduct of monetary policy and to have an effective monetary transmission. This is known as 'impossible trinity', which suggests that no country can enjoy (i) a fixed exchange rate, (ii) open capital account, and (iii) an independent monetary policy. 
Sri Lanka could be due to increased penetration and developments in the stock market activity in recent decades.

Finally, a summary VAR model is estimated to isolate and identify the workings of the traditional direct interest rate channel in the presence of other channels. Accordingly, the baseline unrestricted VAR model is estimated including variables for bank lending, exchange rates and asset prices and hence the relevant model comprises of $G D P_{t}, C P I_{t}$, $M 1_{t}, R L O A N_{t}, S M I_{t}, M M R_{t}$ and $E X R_{t}$ (in the given order) as well as an exchange rate dummy (EXR_DUM) to control for structural changes that occurred due to exchange rate liberalisation. Relevant model is estimated by including bank loans, the nominal exchange rate and the stock market index and then, output and price responses are compared with and without these variables exogenised. Based on these model estimates, Figure 9 presents IRFs for the direct interest rate channel.

Figure 9: Comparison of Direct Interest Rates and Other Channels
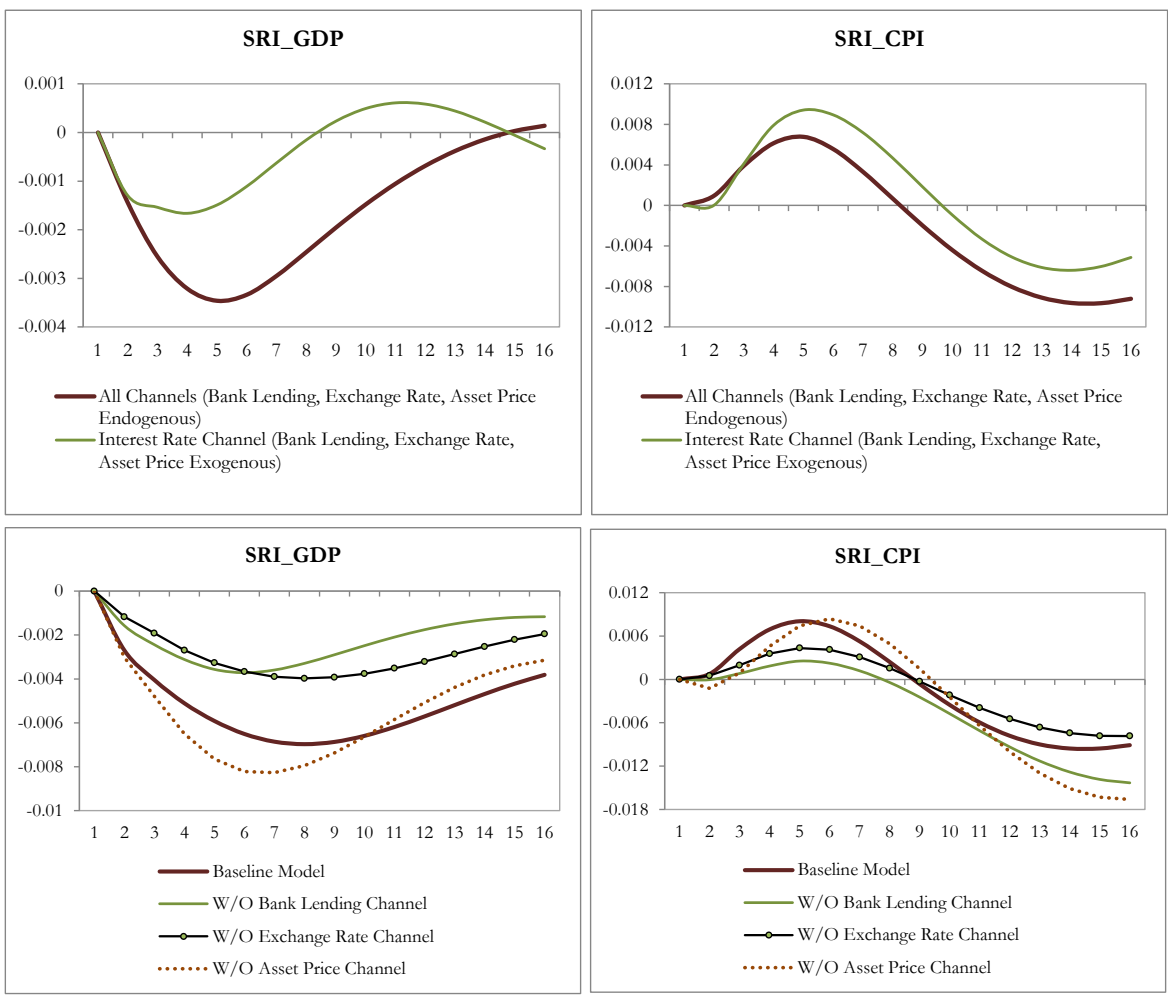
First two graphs presented in Figure 9 suggests that the interest rate channel accounts for about one third of the responses of output (SRI_GDP) and prices (SRI_CPI), particularly after about four quarters. In other words, the other three channels (bank lending, exchange rates and asset prices) together explain the remainder. The other two graphs in the lower panel ascertain the relative importance of each transmission channel. The left-hand side graph suggests that output (SRI_GDP) response is significantly dampened when bank lending and exchange rate channels are blocked-off indicating the existence of those two channels. Although the asset price channel is not much significant for some time, after the tenth quarter, it shows some importance indicating that asset prices have effects in the long run. A similar scenario is observed for responses in prices (SRI_CPI) in the right-hand side graph. In particular, in the long run (after about 9-10 quarters), the impact of exchange rates appears to be playing a significant role in explaining price dynamics.

Overall, the results broadly support the existence of four core conduits in transmitting monetary policy shocks in the Sri Lankan economy despite their relative strength being different. Hence it can be argued that an unanticipated increase in short-term interest rate (a restrictive monetary shock) causes reductions in real GDP and consumer price levels via interest rates, credit, exchange rates and asset prices. Nevertheless, it is important to investigate each channel more closely and extensively in order to completely understand the mechanism of propagation of monetary policy shocks in Sri Lanka. In particular, as seen in recent research into the Sri Lankan context, for example, Perera, Ralston and Wickramanayake (2014), sub-channels of broad credit channel need to examined extensively.

\section{Summary and Conclusions}

This study finds that interest rate pass-through in Sri Lanka is not complete. Despite the fact that short term lending rates, particularly prime lending rates show some speedy and complete adjustment, a majority of interest rates report sluggish and incomplete adjustments. This calls for the need for implementing policies to further develop the financial and banking sector in Sri Lanka while promoting competition among financial intermediaries. Also, it is observed that prime lending rates and 3-months fixed deposit rate of commercial banks have a strong association with money market interest rates. It may therefore be argued that using short-term rates would be much appropriate when assessing the effectiveness of monetary policy. Nevertheless, as the 3-months fixed deposit rate is based on the stock of deposits, it is important to compile the same based on new deposits to reflect the current interest rate environment. 
In the second part of the empirical analysis, it is observed that an unanticipated increase in short-term interest rate (a restrictive monetary policy shock) causes reductions in real GDP and consumer price levels. In particular, both recursive and non-recursive VAR models provide robust and consistent results in relation to the impact of (restrictive) monetary policy shocks on (declining) output and prices. Also, it is noted that an unanticipated increase in the short-term interest rate (a restrictive monetary policy shock) causes reductions in real GDP and consumer price levels via interest rates, credit, exchange rates and asset prices. The results show that the interest rate channel remains the most important transmission channel in Sri Lanka though the other channels also help to propagate monetary policy shocks. From the CBSL's perspective, these results provide implications, which are consistent with the Bank's move towards a monetary policy framework focusing on indirect instruments of monetary policy. Moreover, as the reaction of target variables has been substantially enhanced, i.e. prices are more responsive to interest rate shocks, it provides a strong justification for moving towards an inflation targeting framework, which is considered as an appropriate monetary policy framework for emerging market economies. ${ }^{28 /}$ It needs to be further validated by specific research into inflation targeting in Sri Lanka [for example, see Perera (2008)]. Hence, the need for conducting more research into monetary policy transmission in Sri Lanka is much pronounced.

28/ Mishkin (2000) argues that although inflation targeting is not a panacea, it can be highly useful for monetary policy in a number of emerging market economies. 


\section{Appendix I}

The structural representation of the VAR model of order $p$ takes the following general form:

$$
A_{0} y_{t}=c_{0}+\sum_{i=1}^{p} A_{i} y_{t-i}+\varepsilon_{t}
$$

where, $y_{t}$ is a $7 \times 1$ vector of endogenous variables, i.e., $y_{t}=\left(C O M P_{t}, F E D R_{t}, G D P_{t}\right.$, $\left.C P I_{t}, M 1_{t}, M M R_{t}, E X R_{t}\right), A_{0}$ represents the $7 \times 7$ contemporaneous matrix, $A_{i}$ are $7 \times 7$ autoregressive coefficient matrices, $\varepsilon_{t}$ is a $7 \times 1$ vector of structural disturbances, assumed to have zero covariance. The covariance matrix of the structural disturbances takes the

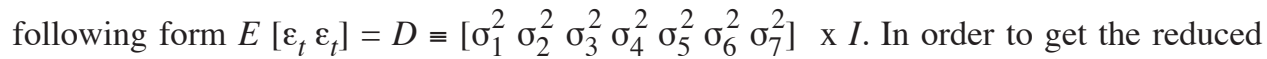
form of the structural model [Eq. (10)], both sides are multiplied with $\mathrm{A}_{0}^{-1}$ providing the following:

$$
y_{t}=a_{0}+\sum_{i=1}^{p} B_{i} y_{t-i}+e_{t}
$$

where, $a_{0}=\mathrm{A}_{0}^{-1} c_{0}, B_{i}=\mathrm{A}_{0}^{-1} A_{i}$ and $e_{t}=\mathrm{A}_{0}^{-1} \varepsilon_{t}$, i.e., $\varepsilon_{t}=A_{0} e_{t}$. The reduced form errors $e_{t}$ are linear combinations of the structural errors $\varepsilon_{t}$, with a covariance matrix of the form $E\left[e_{t} e_{t}\right]=\mathrm{A}_{0}^{-1} \mathrm{DA}_{0}^{-1}$. The structural disturbances can be derived by imposing appropriate restrictions on $A_{0} \cdot{ }^{29 /}$ Accordingly, the short-run restrictions applied in this model are the following:

$$
\left[\begin{array}{l}
\varepsilon_{\text {comps }} \\
\varepsilon_{\text {fedrs }} \\
\varepsilon_{\text {gdps }} \\
\varepsilon_{\text {cpis }} \\
\varepsilon_{m 1 s} \\
\varepsilon_{\text {mmrs }} \\
\varepsilon_{\text {exrs }}
\end{array}\right]=\left[\begin{array}{ccccccc}
1 & 0 & 0 & 0 & 0 & 0 & 0 \\
a_{21} & 1 & 0 & 0 & 0 & 0 & 0 \\
a_{31} & 0 & 1 & 0 & 0 & 0 & 0 \\
a_{41} & 0 & a_{43} & 1 & 0 & 0 & 0 \\
0 & 0 & a_{53} & a_{54} & 1 & a_{56} & 0 \\
a_{61} & 0 & 0 & 0 & a_{65} & 1 & a_{67} \\
a_{71} & a_{72} & a_{73} & a_{74} & a_{75} & a_{76} & 1
\end{array}\right] \times\left[\begin{array}{c}
e_{c o m p} \\
e_{f e d r} \\
e_{g d p} \\
e_{c p i} \\
e_{m 1} \\
e_{m m r} \\
e_{\text {exr }}
\end{array}\right]
$$

29/ Method suggested by Amisano and Giannini (1997), i.e., the A-B model is employed to identify the SVAR. Innovations can be represented as $A u_{t}=B e_{t}$, where $u_{t}$ represents the structural error and $e_{t}$ is the reduced form shocks. This strategy imposes enough restrictions on both matrices. 
where, comps is world commodity price shocks, fedrs is Federal funds rate shock, $g d p s$ is real output (income) shock, cpis is price shock, $m 1 s$ is money supply shock, mmrs is interest rate (monetary policy shock) and exrs is exchange rate shock and all are structural disturbances. $e_{c o m p}$ to $e_{e x r}$ are the residuals in the reduced form equations, which represent the unexpected movements (given information in the system) of each variable. The analysis concentrates on the interaction between monetary policy and output and price developments, identified based on the structural shocks that consist several blocks.

The first two rows in matrix given by Eq. (A.3) is the exogenous block, which represents the shocks originating in the external world, and is given by world commodity prices $\left(C O M P_{t}\right)$ and the Federal funds rate $\left(F E D R_{t}\right)$. The global commodity price of the IMF $\left(C O M P_{t}\right)$ is used instead of oil prices to isolate negative external supply shocks and it is ordered first because commodity prices are unlikely to be affected contemporaneously by any other shocks except the commodity price (supply) shocks per se, while commodity price shocks are likely to affect all variables in the system contemporaneously. Since the monetary authority follows a feedback rule by reacting to information in the economy when setting its monetary policy, the model is also controlled for the systematic component of the policy rule in order to identify the exogenous monetary policy changes (Kim and Roubini, 2000). Accordingly, the Federal funds rate $\left(F E D R_{t}\right)$ is used to isolate the exogenous monetary policy changes, i.e., to control for the component of domestic monetary policy that is a reaction to foreign monetary policy shocks. The identifying restriction in the equations for commodity prices and for Federal funds rates [Rows 1 and 2 in Eq. (A.3)] considers these variables as being contemporaneously exogenous to any variable in the domestic economy.

Real output $\left(G D P_{t}\right)$ and prices $\left(C P I_{t}\right)$ in Row 3 and 4, respectively represent goods market equilibrium. A large number of zero restrictions in these rows is consistent with a model exhibiting nominal rigidities (Elbourne and de Haan, 2006). Hence, money, interest rates or exchange rates do not affect real activity and prices contemporaneously. ${ }^{30 /}$ However, commodity prices do enter this block, based on a cost mark-up rule for prices (Elbourne and de Haan, 2006). Furthermore, price levels respond contemporaneously to real activity as the equation for prices include, the impact of GDP on CPI. Hence, inflation reacts contemporaneously only to an income shock and a global shock (Kim and Roubini, 2000).

Money supply $\left(M 1_{t}\right)$ and the money market rate $\left(M M R_{t}\right)$ in Row 5 and 6 , respectively, represent money market equilibrium. The money demand equation in Row 5 indicates that demand for real money balances is dependent on real income, prices and the interest rate. This indicates that money is responsive to income, price and monetary policy

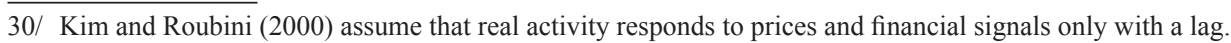


shocks (Chatziantoniou, Duffy, and Filis, 2013). The money market rate, i.e., equation in Row 6 represents the reaction function of the monetary authority that depends on global commodity prices, monetary aggregates and nominal exchange rates (Kim and Roubini, 2000). Following Sims and Zha (1998), it is assumed that monetary policy does not respond contemporaneously to output or prices since relevant data are not available contemporaneously. Also, the reaction function of the monetary authority does not depend on current values of the Federal funds rate. One justification for this assumption is that, contemporaneously, monetary authorities care more about unexpected changes in the exchange rate (for example, against the US dollar) rather than unexpected changes in (for example, the US) interest rates per se or contemporaneously, (the US) interest rate does not have additional information for other (non-US) monetary authorities after they consider their exchange rate against foreign currency (Kim and Roubini, 2000). By including the commodity price and the exchange rate in the reaction function, it is controlled for current systematic responses of monetary policy to the state of the economy. ${ }^{31 /}$

Finally, Row 7 is based on an arbitrage equation describing the exchange rate market and it considers the effects of identified monetary shocks on the value of domestic currency. This equation allows the exchange rate to respond contemporaneously to all variables considering the assumption that exchange rate is a financial variable, i.e., a forward looking asset price, which reacts immediately to information and hence has contemporaneous effects generated by all variables (Kim and Roubini, 2000; Elbourne and de Haan, 2006).

31/ The assumptions of Kim and Roubini (2000) for exchange rates are still valid for an emerging market economy like Sri Lanka. On the one hand, similar to many other countries, Sri Lanka has been implicitly and explicitly concerned about the effects of a depreciation of domestic currency on the developments in inflation. On the other hand, by controlling for components of interest rate movements that are systematic responses to a depreciation of the domestic currency, it is possible to identify interest rate innovations that are exogenous contractions in monetary policy and that should lead to a currency appreciation. 


\section{Appendix II}

\section{Table A.1: Estimates of 7-Variable Structural VAR Model}

This table presents the estimates for 7-variable SVAR model for quarterly data for the period March 1996-December 2012). Short-run restrictions are given in matrix A. C(1) to C(12) are estimated coefficients. LR statistic is used to test for over-identification.

Model: $\mathrm{Ae}=\mathrm{Bu}$ where $\mathrm{E}\left[\mathrm{uu} \mathbf{u}^{\prime}\right]=\mathrm{I}$

Restriction Type: short-run pattern matrix

$\mathrm{A}=$

$\begin{array}{rrrrrrr}1 & 0 & 0 & 0 & 0 & 0 & 0 \\ \mathrm{C}(1) & 1 & 0 & 0 & 0 & 0 & 0 \\ \mathrm{C}(2) & 0 & 1 & 0 & 0 & 0 & 0 \\ \mathrm{C}(3) & 0 & \mathrm{C}(7) & 1 & 0 & 0 & 0 \\ 0 & 0 & \mathrm{C}(8) & \mathrm{C}(10) & 1 & \mathrm{C}(14) & 0 \\ \mathrm{C}(4) & 0 & 0 & 0 & \mathrm{C}(12) & 1 & \mathrm{C}(16) \\ \mathrm{C}(5) & \mathrm{C}(6) & \mathrm{C}(9) & \mathrm{C}(11) & \mathrm{C}(13) & \mathrm{C}(15) & 1\end{array}$

$\mathrm{B}=$

\begin{tabular}{rrrrrrr}
$\mathrm{C}(17)$ & 0 & 0 & 0 & 0 & 0 & 0 \\
0 & $\mathrm{C}(18)$ & 0 & 0 & 0 & 0 & 0 \\
0 & 0 & $\mathrm{C}(19)$ & 0 & 0 & 0 & 0 \\
0 & 0 & 0 & $\mathrm{C}(20)$ & 0 & 0 & 0 \\
0 & 0 & 0 & 0 & $\mathrm{C}(21)$ & 0 & 0 \\
0 & 0 & 0 & 0 & 0 & $\mathrm{C}(22)$ & 0 \\
0 & 0 & 0 & 0 & 0 & 0 & $\mathrm{C}(23)$ \\
\hline
\end{tabular}

(Contd.) 


\section{Coefficient Std. Error z-Statistic Prob.}

$\begin{array}{lcrrr}\mathrm{C}(1) & -0.865189 & 0.421009 & -2.055037 & 0.0399 \\ \mathrm{C}(2) & -0.038896 & 0.017777 & -2.187993 & 0.0287 \\ \mathrm{C}(3) & -0.102516 & 0.026439 & -3.877503 & 0.0001 \\ \mathrm{C}(4) & 0.178616 & 4.364433 & 0.040925 & 0.9674 \\ \mathrm{C}(5) & 0.093286 & 0.042359 & 2.202275 & 0.0276 \\ \mathrm{C}(6) & -0.004591 & 0.010005 & -0.458852 & 0.6463 \\ \mathrm{C}(7) & 0.032250 & 0.178029 & 0.181152 & 0.8562 \\ \mathrm{C}(8) & 0.010603 & 0.456265 & 0.023239 & 0.9815 \\ \mathrm{C}(9) & 0.518216 & 0.248207 & 2.087836 & 0.0368 \\ \mathrm{C}(10) & 0.012305 & 0.199297 & 0.061742 & 0.9508 \\ \mathrm{C}(11) & -0.303184 & 0.170573 & -1.777449 & 0.0755 \\ \mathrm{C}(12) & -46.629860 & 129.3019 & -0.360628 & 0.7184 \\ \mathrm{C}(13) & -0.074215 & 0.379333 & -0.195646 & 0.8449 \\ \mathrm{C}(14) & 0.012854 & 0.021184 & 0.606795 & 0.5440 \\ \mathrm{C}(15) & 0.000129 & 0.005575 & 0.023103 & 0.9816 \\ \mathrm{C}(16) & -40.409900 & 54.72498 & -0.738418 & 0.4603 \\ \mathrm{C}(17) & 0.071399 & 0.006262 & 11.40175 & 0.0000 \\ \mathrm{C}(18) & 0.242349 & 0.021255 & 11.40175 & 0.0000 \\ \mathrm{C}(19) & 0.010233 & 0.000898 & 11.40175 & 0.0000 \\ \mathrm{C}(20) & 0.014688 & 0.001288 & 11.40175 & 0.0000 \\ \mathrm{C}(21) & 0.024948 & 0.016112 & 1.548445 & 0.1215 \\ \mathrm{C}(22) & 1.968424 & 2.053040 & 0.958785 & 0.3377 \\ \mathrm{C}(23) & 0.019505 & 0.003312 & 5.889142 & 0.0000 \\ \mathrm{C} & & & \end{array}$

Log likelihood

674.35

LR test for over-identification:

Chi-square(5) $\quad 8.673$

Probability 0.1395

Estimated A matrix:

\begin{tabular}{lcccccc}
1.000000 & 0.000000 & 0.000000 & 0.000000 & 0.000000 & 0.000000 & 0.000000 \\
-0.865189 & 1.000000 & 0.000000 & 0.000000 & 0.000000 & 0.000000 & 0.000000 \\
-0.038896 & 0.000000 & 1.000000 & 0.000000 & 0.000000 & 0.000000 & 0.000000 \\
-0.102516 & 0.000000 & 0.032250 & 1.000000 & 0.000000 & 0.000000 & 0.000000 \\
0.000000 & 0.000000 & 0.010603 & 0.012305 & 1.000000 & 0.012854 & 0.000000 \\
0.178616 & 0.000000 & 0.000000 & 0.000000 & -46.62986 & 1.000000 & -40.4099 \\
0.093286 & -0.004591 & 0.518216 & -0.303184 & -0.074215 & 0.000129 & 1.000000 \\
Estimated B matrix : & & & & & & \\
0.071399 & 0.000000 & 0.000000 & 0.000000 & 0.000000 & 0.000000 & 0.000000 \\
0.000000 & 0.242349 & 0.000000 & 0.000000 & 0.000000 & 0.000000 & 0.000000 \\
0.000000 & 0.000000 & 0.010233 & 0.000000 & 0.000000 & 0.000000 & 0.000000 \\
0.000000 & 0.000000 & 0.000000 & 0.014688 & 0.000000 & 0.000000 & 0.000000 \\
0.000000 & 0.000000 & 0.000000 & 0.000000 & 0.024948 & 0.000000 & 0.000000 \\
0.000000 & 0.000000 & 0.000000 & 0.000000 & 0.000000 & 1.968424 & 0.000000 \\
0.000000 & 0.000000 & 0.000000 & 0.000000 & 0.000000 & 0.000000 & 0.019505 \\
\hline \hline
\end{tabular}




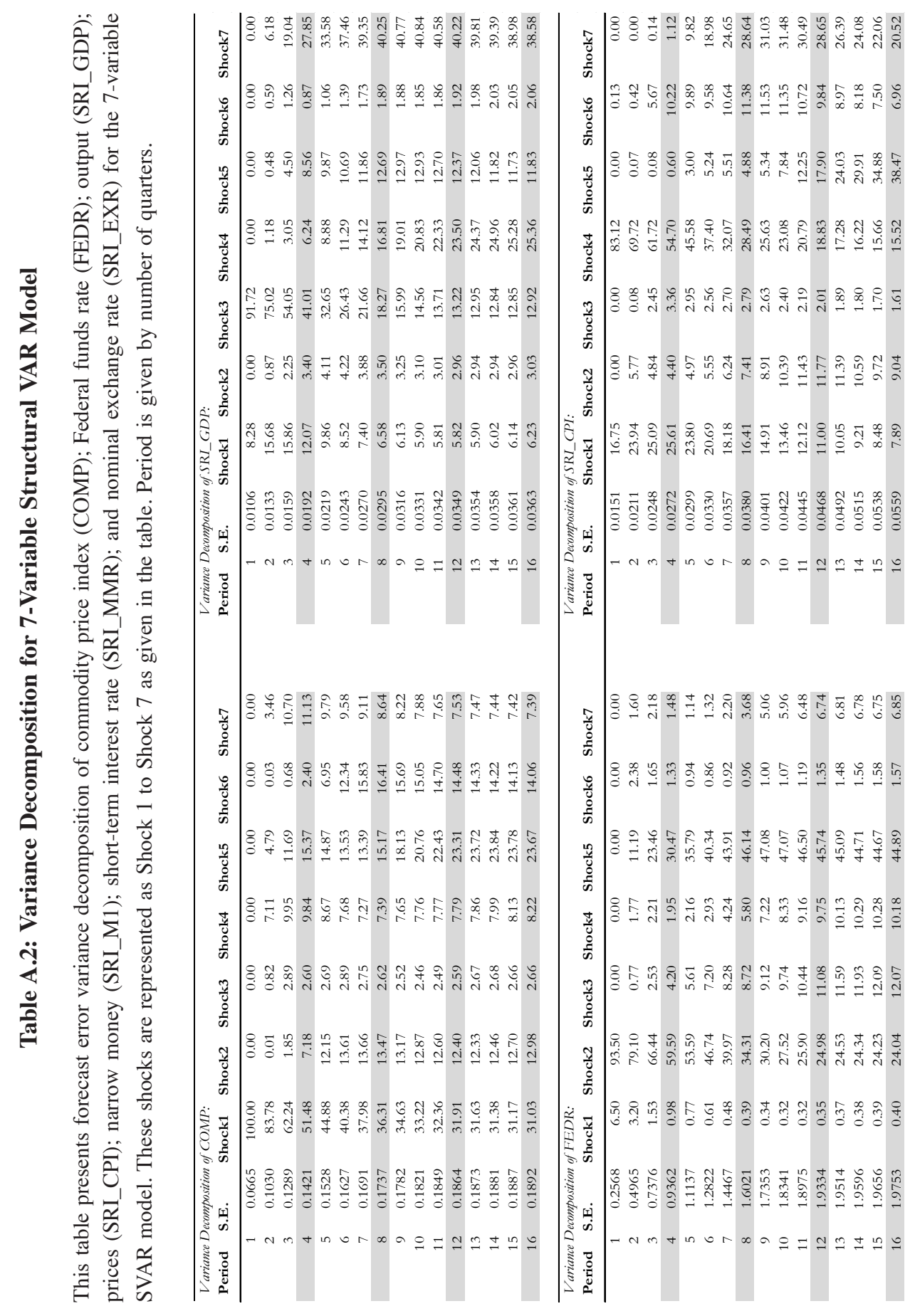




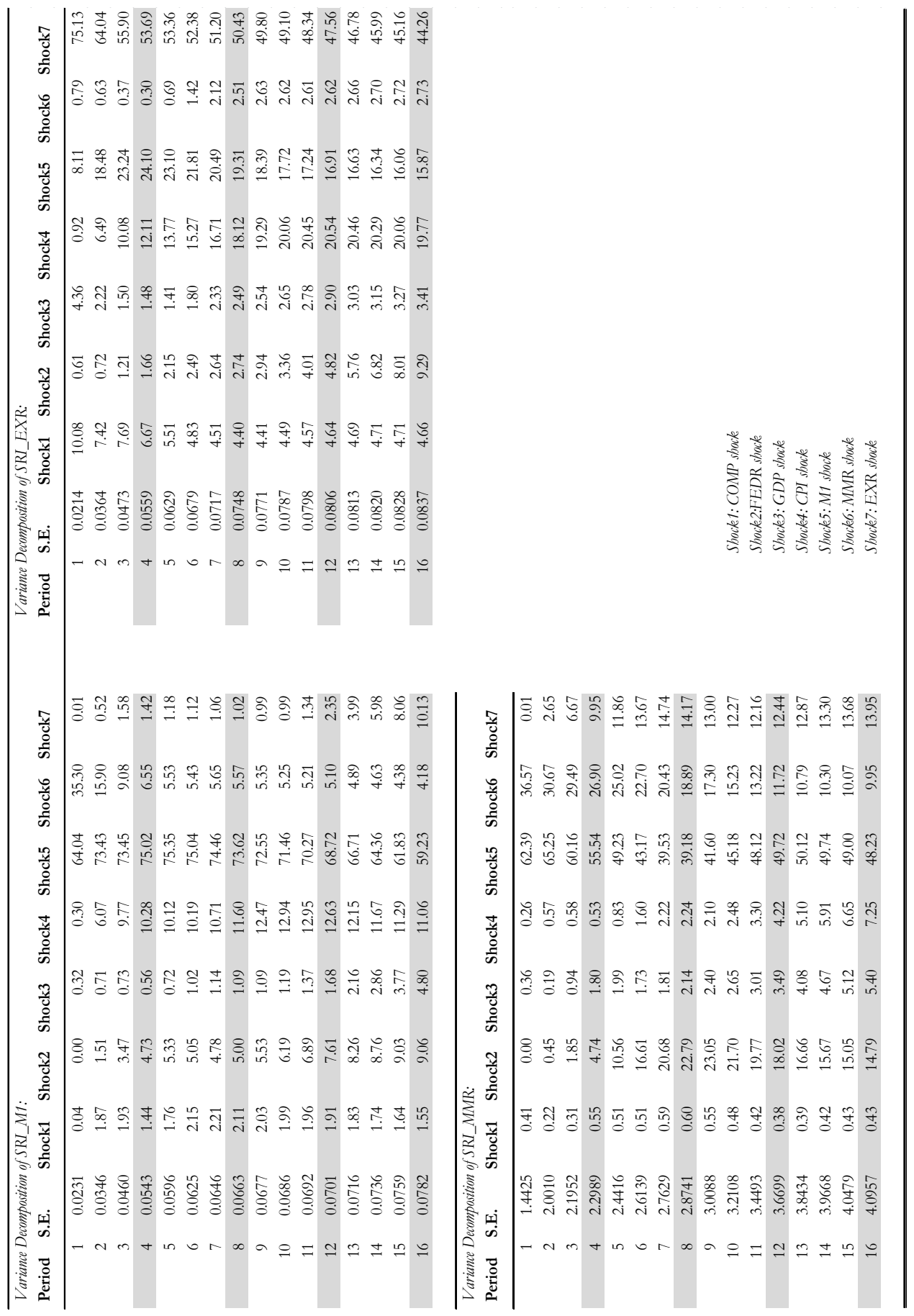




\section{References}

Aazim, M. Z. M., and Cooray, N. S. (2012). Monetary Policy and Yield Curve Dynamics in An Emerging Market: Sri Lankan Perspectives. South Asian Journal of Macroeconomics and Public Finance, 1(1), 25-56.

Afandi, A. (2005). Monetary Policy Transmission Mechanism and Structural Breaks in Indonesia. Doctoral Thesis, University of Wollongong.

Agung, J. (1998). Financial Deregulation and the Bank Lending Channel in Developing Countries: The case of Indonesia. Asian Economic Journal, 12(3), 273-294.

Alles, L. (2008). The Cost of Downside Protection and the Time Diversification Issue in South Asian Stock Markets. Applied Financial Economics, 18(10), 835-843.

Amarasekara, C. (2005). Interest Rate Pass-Through in Sri Lanka. Staff Studies, Central Bank of Sri Lanka, Colombo, 35(1\&2), 1-32.

Amarasekara, C. (2008). The Impact of Monetary Policy on Economic Growth and Inflation in Sri Lanka. Staff Studies, Central Bank of Sri Lanka, 38(1\&2), 2-44.

Amisano, G., and Giannini, C. (1997). Topics in Structural VAR Econometrics. Springer, Berlin.

Arin, K. P., and Jolly, S . (2005). Trans-Tasman Transmission of Monetary Shocks: Evidence from a VAR Approach. Atlantic Economic Journal, 33(3), 267-283.

Athukorala, P., and Rajapatirana, S. (1993). Liberalization of the Domestic Financial Market: Theoretical Issues with eEvidence from Sri Lanka. International Economic Journal, 7(4), 17-33.

Aysun, U., and Hepp, R. (2011). Securitization and the Balance Sheet Channel of Monetary Transmission. Journal of Banking \& Finance, 35(8), 2111-2122.

Berkelmans, L. (2005). Credit and Monetary Policy: An Australian SVAR. Research Discussion Papers of Reserve Bank of Australia, 2005-06.

Bernanke, B. S., and Blinder, A. S. (1988). Credit, Money, and Aggregate Demand. American Economic Review, 78(2), 435-439.

Bernanke, B. S., and Gertler, M. (1995). Inside the Black Box: The Credit Channel of Monetary Policy Transmission. Journal of Economic Perspectives, 9(4), 27-48. 
Berument, H., and Froyen, R. T. (2006). Monetary Policy and Long-Term US Interest Rates. Journal of Macroeconomics, 28(4), 737-751.

Boivin, J., and Giannoni, M. P. (2006). Has Monetary Policy Become More Effective? Review of Economics and Statistics, 88(3), 445-462.

Boivin, J., Kiley, M. T., and Mishkin, F. S. (2010). How has the Monetary Transmission Mechanism Evolved Over Time? Finance and Economics Discussion Series, Federal Reserve Board, Washington, 26.

Bolton, P., and Freixas, X. (2006). Corporate Finance and the Monetary Transmission Mechanism. Review of Financial Studies, 19(3), 829-870.

Bredin, D., Fitzpatrick, T., and O'Reilly, G. (2002). Retail Interest Rate Pass-Though: The Irish Experience. Economic and Social Review, 33(2), Summer/Autumn, 223-246.

Brooks, C. (2008). Introductory Econometrics for Finance (Second ed.). Cambridge University Press, Cambridge.

Carpenter, S., and Demiralp, S. (2012). Money, Reserves, and the Transmission of Monetary Policy: Does the Money Multiplier Exist? Journal of Macroeconomics, 34(1), 59-75.

Cecchetti, S. G., Flores-Lagunes, A., and Krause, S. (2006). Has the Monetary Policy Become More Efficient? A Cross-Country Analysis. The Economic Journal, 116(511), 408-433.

Central Bank of Sri Lanka (1998). Economic Progress of Independent Sri Lanka. Central Bank of Sri Lanka, Colombo.

Central Bank of Sri Lanka (2005). Objectives, Functions and Organization. Central Bank of Sri Lanka, Colombo.

Central Bank of Sri Lanka (2010). Annual Report 2010. Central Bank of Sri Lanka, Colombo.

Central Bank of Sri Lanka (2011). Road Map: Monetary and Financial Sector Policies for 2011 and Beyond. Central Bank of Sri Lanka, Colombo.

Central Bank of Sri Lanka. (2012). Road Map: Monetary and Financial Sector Policies for 2012 and Beyond. Central Bank of Sri Lanka, Colombo.

Charoenseang, J., and Manakit, P. (2007). Thai Monetary Policy Transmission in An Inflation Targeting Era. Journal of Asian Economics, 18(1), 144-157. 
Chatziantoniou, I., Duffy, D., and Filis, G. (2013). Stock Market Response to Monetary and Fiscal Policy Shocks: Multi-Country Evidence. Economic Modelling, 30(0), 754-769.

Chong, B. S. (2010). Interest rate deregulation: Monetary Policy Efficacy and Rate Rigidity. Journal of Banking \& Finance, 34(6), 1299-1307.

Chong, B. S., Liu, M. H., and Shrestha, K. (2006). Monetary Transmission via the Administered Interest Rates Channel. Journal of Banking \& Finance, 30(5), 1467-1484.

Cole, R. A., Moshirian, F., and Wu, Q. (2008). Bank Stock Returns and Economic Growth. Journal of Banking \& Finance, 32(6), 995-1007.

Cook, D. (2004). Monetary Policy in Emerging Markets: Can Liability Dollarization Explain Contractionary Devaluations? Journal of Monetary Economics, 51(6), 11551181.

Cooper, R. N. (1992). Economic Stabilization and Debt in Developing Countries. MIT Press, Cambridge, MA.

Cooray, A. (2000). The Impact on the Deregulation on Financial Market Efficiency in Sri Lanka. Doctoral Thesis, University of New South Wales.

Cottarelli, C., and Kourelis, A. (1994). Financial Structure, Bank Lending Rates, and the Transmission Mechanism of Monetary Policy. Staff Papers of International Monetary Fund, Washington D.C., 41(4), 587-623.

Cuthbertson, A. G., and Athukorala, P. (1990). Liberalizing Foreign Trade: The Experience of Sri Lanka. In Choksi, A. M., Michaely, M., and Papageorgious, D. (Eds.), Liberalizing Foreign Trade: The Experience of Indonesia, Pakistan and Sri Lanka (pp. 287-428). Basil Blackwell, Oxford.

Dale, S., and Haldane, A. G. (1995). Interest Rates and the Channels of Monetary Transmission: Some Sectoral Estimates. European Economic Review, 39(9), 16111626.

De Bondt, G., J. (2005). Interest Rate Pass-Through: Empirical Results for the Euro Area. German Economic Review, 6(1), 37-78.

De Graeve, F., De Jonghe, O., and Vennet, R. V. (2007). Competition, Transmission and Bank Pricing Policies: Evidence from Belgian Loan and Deposit Markets. Journal of Banking \& Finance 31(1), 259-278. 
Devereux, M. B., Lane, P. R., and Xu, J. (2006). Exchange Rates and Monetary Policy in Emerging Market Economies. The Economic Journal, 116(511), 478-506.

Diebold, F. X., and Sharpe, S. A. (1990). Post-Deregulation Bank-Deposit-Rate Pricing: The Multivariate Dynamics. Journal of Business \& Economic Statistics, 8(3), 281-291.

Disyatat, P., and Vongsinsirikul, P. (2003). Monetary Policy and the Transmission Mechanism in Thailand. Journal of Asian Economics 14(3), 389-418.

Duguay, P. (1994). Empirical Evidence on the Strength of the Monetary Transmission Mechanism in Canada: An Aggregate Approach. Journal of Monetary Economics, 33(1), 39-61.

Dungey, M., and Pagan, A. (2000). A Structural VAR Model of the Australian Economy. Economic Record, 76(235), 321-342.

Égert, B., Crespo-Cuaresma, J., and Reininger, T. (2007). Interest Rate Pass-Through in Central and Eastern Europe: Reborn from Ashes Merely to Pass Away? Journal of Policy Modeling, 29(2), 209-225.

Égert, B., and Jamilov, R. (2014). Interest Rate Pass-Through and Monetary Policy Asymmetry: A Journey into the Caucasian Black Box. Journal of Asian Economics (0).

Égert, B., and MacDonald, R. (2009). Monetary Transmission Mechanism in Central and Eastern Europe: Surveying the Surveyable. Journal of Economic Surveys, 23(2), $277-327$.

Elbourne, A. (2008). The UK Housing Market and the Monetary Policy Transmission Mechanism: An SVAR Approach. Journal of Housing Economics, 17(1), 65-87.

Elbourne, A., and de Haan, J. (2006). Financial Structure and Monetary Policy Transmission in Transition Countries. Journal of Comparative Economics, 34(1), 1-23.

Engle, R. F., and Granger, C. W. J. (1987). Co-Integration and Error Correction: Representation, Estimation and Testing. Econometrica, 55(2), 251-276.

Espinosa-Vega, M. A., and Rebucci, A. (2004). Retail Bank Interest Rate Pass-Through: Is Chile Atypical? In Ahumada, L. A., and Fuentes, J. R. (Eds.), Banking Market Structure and Monetary Policy (pp. 147-182). Central Bank of Chile. Santiago, Chile.

Fraser, P., Macdonald, G. A., and Mullineux, A. W. (2012). Regional Monetary Policy: An Australian Perspective. Regional Studies, 1-15. 
Fuertes, A.-M., and Heffernan, S. A. (2009). Interest Rate Transmission in the UK: A Comparative Analysis across Financial Firms and Products. International Journal of Finance \& Economics, 14(1), 45-63.

Garretsen, H., and Swank, J. (1998). The Transmission of Interest Rate Changes and The Role of Bank Balance Sheets: A VAR-Analysis for the Netherlands. Journal of Macroeconomics, 20(2), 325-339.

Gerlach, S., and Smets, F. (1995). The Monetary Transmission Mechanism: Evidence from the G-7 Countries. Working Paper of Bank for International Settlements, 26.

Gertler, M., and Gilchrist, S. (1993). The Role of Credit Market Imperfections in the Monetary Transmission Mechanism: Arguments and Evidence. The Scandinavian Journal of Economics, 95(1), 43-64.

Granger, C. W. J. (1969). Investigating Casual Relations by Econometric Models and Cross Spectral Methods. Econometrica, 37(3), 424-438.

Granger, C. W. J. (1981). Some Properties of Time Series Data and Their Use in Econometric Model Specification. Journal of Econometrics, 16(1), 121-130.

Hannan, T. H., and Berger, A. N. (1991). The Rigidity of Prices: Evidence from the Banking Industry. American Economic Review, 81(4), 938-945.

Haughton, A. Y., and Iglesias, E. M. (2012). Interest Rate Volatility, Asymmetric Interest Rate Pass-Through and the Monetary Transmission Mechanism in the Caribbean Compared to US and Asia. Economic Modelling, 29(6), 2071-2089.

Heffernan, S. A. (1997). Modelling British Interest Rate Adjustment: An Error Correction Approach. Economica, 64, 211-231.

Hendry, D. F. (1995). Dynamic Econometrics. Oxford University Press.

Hesse, H. (2007). Monetary Policy, Structural Break and the Monetary Transmission Mechanism in Thailand. Journal of Asian Economics, 18(4), 649-669.

Hofmann, B. (2006). EMU and the Transmission of Monetary Policy: Evidence from Business Lending Rates. Empirica, 33, 209-229.

Hofmann, B., and Mizen,P. (2004). Interest Rate Pass-Through and Monetary Transmission: Evidence from Individual Financial Institutions' Retail Rates. Economica, New Series, 71(281, Feb.), 99-123. 
Horváth, R., and Podpiera, A. (2012). Heterogeneity in Bank Pricing Policies: The Czech Evidence. Economic Systems, 36(1), 87-108.

Iacoviello, M., and Minetti, R. (2003). Financial Liberalization and the Sensitivity of House Prices to Monetary Policy: Theory and Evidence. The Manchester School, 71(1), 20-34.

Ireland, P. N. (2008). The Monetary Transmission Mechanism. In Blume, L., and Durlauf, S. (Eds.), The New Palgrave Dictionary of Economics (Second ed.). Palgrave Macmillan. Hampshire.

Ito, T., and Sato, K. (2008). Exchange Rate Changes and Inflation in Post-Crisis Asian Economies: Vector Autoregression Analysis of the Exchange Rate Pass-Through. Journal of Money, Credit and Banking, 40(7), 1407-1438.

Jayamaha, R. (1995). The Monetary Transmission Mechanism in Sri Lanka: 1977-1985. Doctoral Thesis, University of Bradford.

Johansen, S. (1988). Statistical Analysis of Cointegration Vectors. Journal of Economic Dynamics and Control, 12(2-3), 231-254.

Kandrac, J. (2012). Monetary Policy and Bank Lending to Small Firms. Journal of Macroeconomics, 34(3), 741-748.

Kashyap, A. K., and Stein, J. C. (1995). The Impact of Monetary Policy on Bank Balance Sheets. Carnegie Rochester Conference Series on Public Policy 42, 151-195.

Kilponen, J., and Leitemo, K. (2011). Transmission Lags and Optimal Monetary Policy. Journal of Economic Dynamics \& Control 35(4), 565-578.

Kim, S., and Roubini, N. (2000). Exchange Rate Anomalies in the Industrial Countries: A Solution with a Structural VAR Approach. Journal of Monetary Economics, 45(3), 561-586.

Laopodis, N. T. (2013). Monetary Policy and Stock Market Dynamics across Monetary Regimes. Journal of International Money and Finance, 33(0), 381-406.

Leeper, E. M., Sims, C. A., and Zha, T. (1996). What does Monetary Policy do? Brookings Papers on Economic Activity, 2, 1-78.

Li, Y. D., İşcan, T. B., and Xu, K. (2010). The Impact of Monetary Policy Shocks on Stock Prices: Evidence from Canada and the United States. Journal of International Money and Finance, 29(5), 876-896. 
Little, I. M. D., Cooper, R. N., Corden, W. M., and Rajapatirana, S. (1993). Boom, Crisis, and Adjustment: The Macroeconomic Experiences of Developing Countries. Oxford University Press, Oxford.

Liu, M.-H., Margaritis, D., and Tourani-Rad, A. (2008). Monetary Policy Transparency and Pass-Through of Retail Interest Rates. Journal of Banking \& Finance 32(4), 501-511.

Lütkepohl, H., and Reimers, H.-E. (1992). Impulse Response Analysis of Cointegrated Systems. Journal of Economic Dynamics and Control, 16(1), 53-78.

MacDonald, G., Mullineux, A., and Sensarma, R. (2009). Asymmetric Effects of Interest Rate Changes: The Role of the Consumption-Wealth Channel. Applied Economics, 43(16), 1991-2001.

Marotta, G. (2009). Structural Breaks in the Lending Interest Rate Pass-Through and the Euro. Economic Modelling, 26(1), 191-205.

Mishkin, F. S. (1995). Symposium on the Monetary Transmission Mechanism. Journal of Economic Perspectives, 9(4), 3-10.

Mishkin, F. S. (2000). Inflation Targeting in Emerging-Market Countries. American Economic Review, 90(2), 105-109.

Mojon, B. (2000). Financial Structure and the Interest Rate Channel of ECB Monetary Policy. Working Papers of European Central Bank, Frankfurt, 40.

Montiel, P. J., and Servén, L. (2006). Macroeconomic Stability in Developing Countries: How much is enough? The World Bank Research Observer, 21(2), 151-178.

Morris, S., and Sellon, G. H., Jr. (1995). Bank Lending and Monetary Policy: Evidence on a Credit Channel. Federal Reserve of Kansas City Economic Review, Second Quarter, $59-75$.

Morsink, J., and Bayoumi, T. (2001). A Peek Inside the Black Box: The Monetary Transmission Mechanism in Japan. IMF Staff Paper, International Monetary Fund, 48(1), 22-57.

Paudel, R. C., and Jayanthakumaran, K. (2009). Financial Liberalization and Performance in Sri Lanka : The ARDL approach. South Asia Economic Journal, 10(1), 127-156.

Perera,A. (2008). Is Sri Lanka Ready for Inflation Targeting? Paper presented at the Central Banking and Financial Markets, Central Bank of Sri Lanka Inaugural International Research Conference, Colombo. 
Perera, A. (2014). Financial Sector Dynamics, Monetary Policy Transmission and Central Banking: A Cross-Country Analysis. Doctoral Thesis, Monash University.

Perera, A., and Liyanage, E. (2012). An Empirical Investigation of the Twin Deficit Hypothesis: Evidence from Sri Lanka. Staff Studies, Central Bank of Sri Lanka, $41(1 \& 2), 41-88$.

Perera, A., Ralston, D., and Wickramanayake, J. (2014). Impact of Off-Balance Sheet Banking on the Bank Lending Channel of Monetary Transmission: Evidence from South Asia. Journal of International Financial Markets, Institutions and Money, 29 (March), 195-216.

Perera, A., and Wickramanayake, J. (2012). Financial Integration in Selected South Asian Countries. South Asian Journal of Global Business Research, 1(2), 210-237.

Perera, S., Skully, M., and Nguyen, T. N. M. (2012). Market Concentration and Pricing Behaviour of Sri Lankan Banks. South Asian Journal of Global Business Research, 1(1).

Pesaran, M. H., and Pesaran, B. (1997). Working with Microfit 4.0 - Interactive Econometric Analysis. Oxford University Press.

Rafiq, M. S., and Mallick, S. K. (2008). The Effect of Monetary Policy on Output in EMU3: A Sign Restriction Approach. Journal of Macroeconomics, 30(4), 1756-1791.

Roberts, J. M. (1998). Inflation Expectations and the Transmission of Monetary Policy. Fianance and Economics Discussion Series, Federal Reserve System, 43.

Romer, C., and Romer, D. (1994). Credit Channel or Credit Actions? An Interpretation of the Postwar Transmission Mechanism. NBER Working Paper Series, National Bureau of Economic Research, Massachusettes, 4485.

Rousseas, S. (1985). A Markup Theory of Bank Loan Rates. Journal of Post Keynesian Economics, 8(1), 135-144.

Sander, H., and Kleimeier, S. (2006). Convergence of Interest Rate Pass-Through in a Wider Euro Zone? Economic Systems, 30(4), 405-423.

Scholnick, B. (1996). Asymmetric Adjustment of Commercial Bank Interest Rates: Evidence from Malaysia and Singapore. Journal of International Money and Finance, 15(3), 485-496. 
Scholnick, B. (1999). Interest Rate Asymmetries in Long-Term Loan and Deposit Markets. Journal of Financial Services Research, 16(1), 5-26.

Sellin, P. (2001). Monetary Policy and the Stock Market: Theory and Empirical Evidence. Journal of Economic Surveys, 15(4), 491-541.

Sellon, G. H. (2002). The Changing U.S. Financial System: Some Implications for the Monetary Transmission Mechanism. Economic Review, Federal Reserve Bank of Kansas City, First Quarter.

Sims, C. A. (1992). Interpreting the Macroeconomic Time Series Facts: The Effects of Monetary Policy. European Economic Review, 36(5), 975-1000.

Sims, C. A., Stock, J. H., and Watson, M. W. (1990). Inference in Linear Time Series Models with Some Unit Roots. Econometrica, 58(1), 113-144.

Sims, C. A., and Zha, T. (1998). Does Monetary Policy Generate Recessions? Working Paper of Federal Reserve Bank of Atlanta, 12.

Sousa, J. M., and Zaghini, A. (2007). Global Monetary Policy Shocks in the G5: A SVAR Approach. Journal of International Financial Markets, Institutions and Money, 17(5), 403-419.

Stiglitz, J., and Weiss, A. (1981). Credit Rationing in Markets with Imperfect Information. American Economic Review, 71(3), 393-410.

Svensson, L. E. O. (1999). Inflation Targeting as a Monetary Policy Rule. Journal of Monetary Economics, 43(3), 607-654.

Taylor, J. B. (1995). The Monetary Transmission Mechanism: An Empirical Framework. Journal of Economic Perspectives, 9(4), 11-26.

Walsh, C. E. (2010). Monetary Theory and Policy (Third ed.). MIT Press, London.

Woodford, M. (2003). Interest and Prices. Princeton University Press, Princeton, N.J.

Zulkhibri, M. (2012). Policy Rate Pass-Through and the Adjustment of Retail Interest Rates: Empirical Evidence from Malaysian Financial Institutions. Journal of Asian Economics, 23(4), 409-422. 